\title{
Interactions between wildlife and vegetation under different grazing intensities and habitat types in the Knersvlakte, South Africa
}

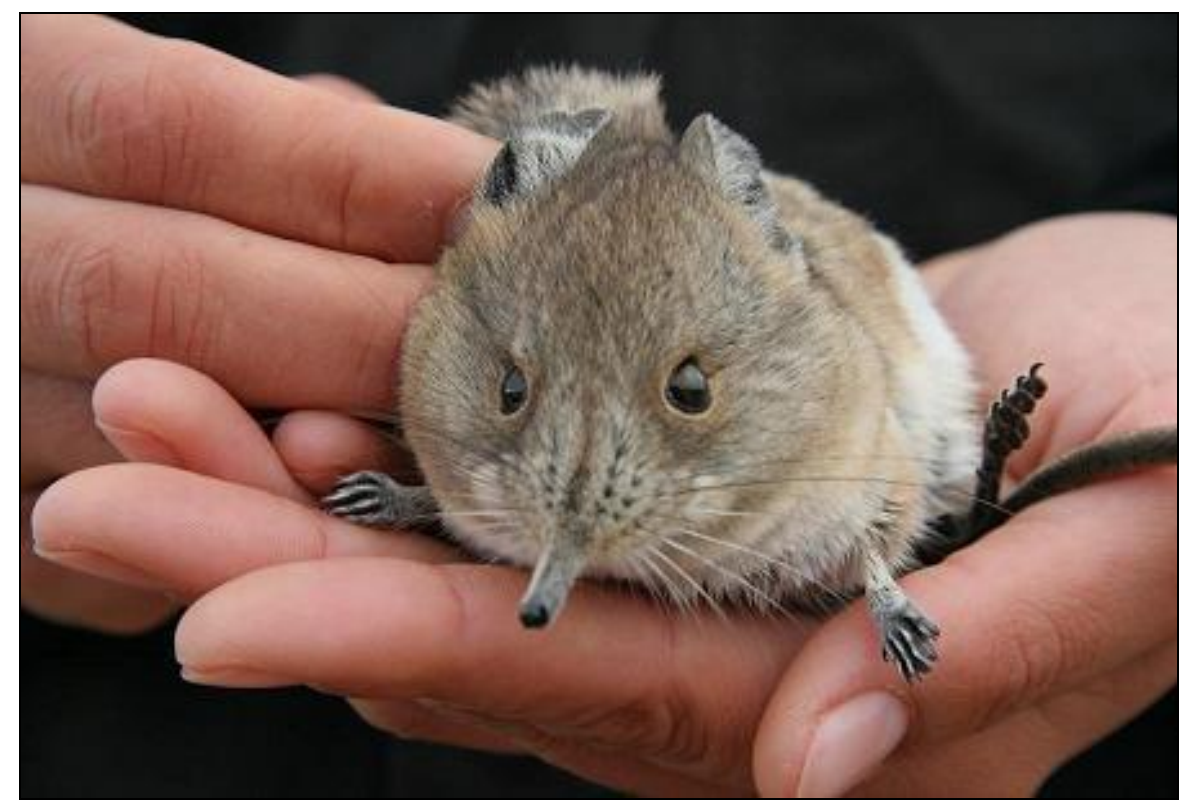

Diploma thesis

Department of Biology

University of Hamburg

First Evaluator: Prof. Dr. J. Ganzhorn

Second Evaluator: Prof. Dr. N. Jürgens

Subject-area reviewer (Fachgutachter): Dr. U. Schmiedel

Submitted by: Britta Mareike Bösing, 22.05.1983, Heilbronn-Neckargartach

Hamburg, February 2009 


\section{Contents}

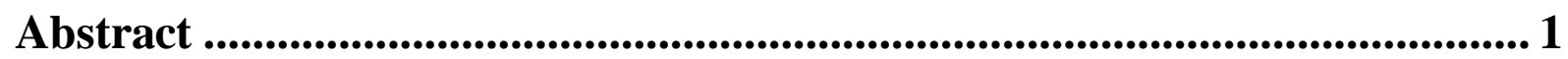

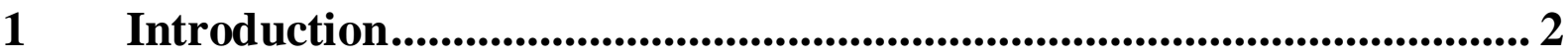

$2 \quad$ Material and methods .................................................................................5 5

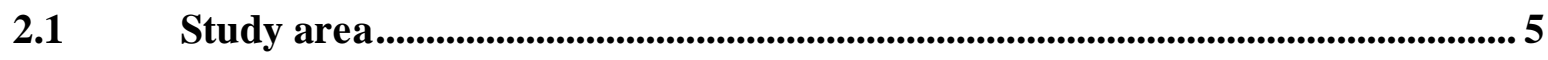

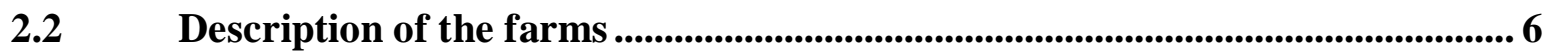

2.3 Small mammal life trapping ...................................................................................................... 8

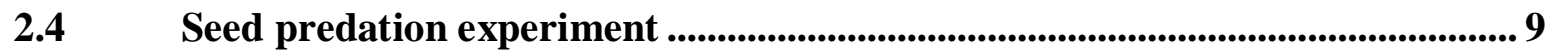

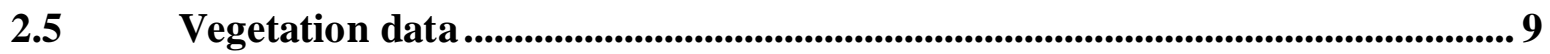

2.6 Germination experiment .......................................................................................... 10

2.7 Weather data, moon size and day of year .................................................. 10

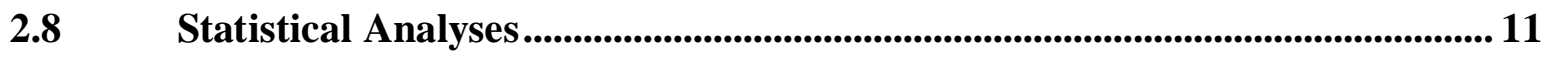

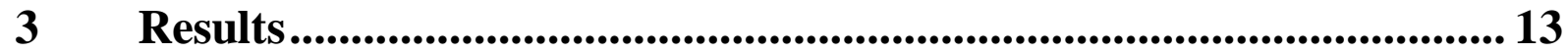

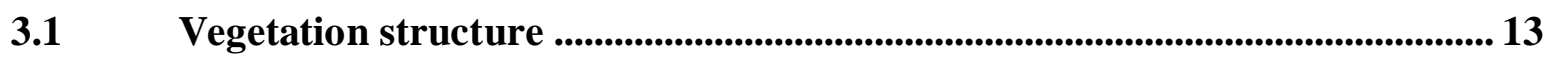

S.2 Species composition of small mammals ........................................................................... 14

$3.3 \quad$ Diversity and activity of small mammals ..................................................... 18

3.4 BMI and body weight of two selected species ..................................................... 20

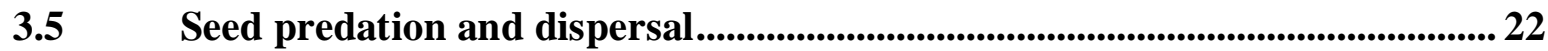

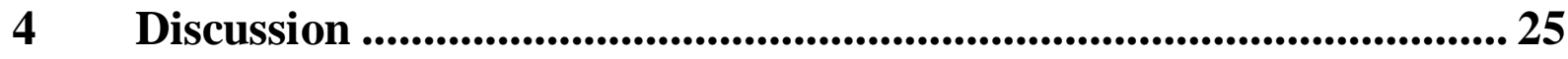

4.1 Effects of habitat type and different grazing intensities on vegetation cover...

4.2 Effects of weather, moon and day of year on small mammals and seed predation

4.3 Effects of habitat type and different grazing intensities on small mammals

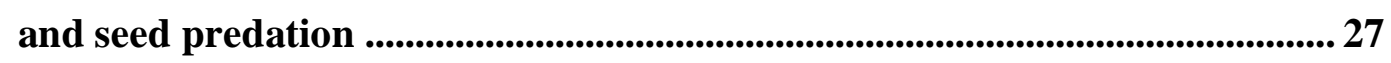

Effects of indigenous herbivores on vegetation .............................................33

4.5 Conclusion and implication for nature conservation .......................................... 34

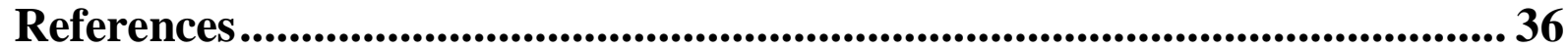

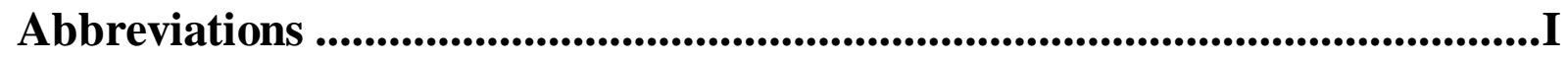

Appendices....................................................................................... II

Acknowledgements....................................................................................... X 


\section{Figures}

Figure 1 Schematic graph showing the analysed interactions between wildlife, vegetation cover, livestock grazing intensity and habitat type.

Figure 2 Location of the Knersvlakte in the western part of South Africa. The study area is located in the projected Knersvlakte Conservation Area.

Figure 3 Scale of the Knersvlakte Conservation Area (Figure 2) and the investigated farms, trap plots and exclosures in detail. CapeNature provided all GIS layers except for the plot locations.

Figure 4 Side-face (left picture) and view from above (right picture) of the round-eared elephant shrew Macroscelides proboscideus.

Figure 5 Side-face (left picture) and view from above (right picture) of the four-striped grass mouse Rhabdomys pumilio.

\section{Tables}

Table 1 Summary of the ANOVA results for the dependence of vegetation cover [\%] around the traps $\left(1 \mathrm{~m}^{2}\right)$ on habitat type in different height classes (mean \pm standard deviation); $p$ values printed in bold indicate significant results; loam $n=12$, quartz $n=10$.

Table 2 Summary of ANOVA results for the dependence of vegetation cover [\%] around the exclosures $\left(4 \mathrm{~m}^{2}\right)$ on habitat type in different height classes (mean \pm standard deviation); $p$-values printed in bold indicate significant results; loam $n=120$, quartz $n=120$.

Table 3 Summary of the ANOVA results for the dependence of vegetation cover [\%] around the traps $\left(1 \mathrm{~m}^{3}\right)$ with different grazing intensities in different heights in the two habitat types (mean \pm standard deviation), (p-values)............................................................. 14

Table 4 Overview of trapped species and food preference, distribution and behaviour.......... 16

Table 5 Trapping success [\%] (mean \pm standard deviation) for different grazing intensities in the two habitat types, ( $p$-values).

Table 6 Overview of trapped species and numbers of individuals (without recaptures) on different habitats under different grazing intensities. $M=$ Macroscelidea, $R=$ Rodentia, $\mathrm{E}=$ Eulipotyphla. Points indicate no captures.

Table 7 Summary of the GLM results for the dependence of number of individuals and species on habitat type (mean \pm standard deviation), $p$-values printed in bold indicate significant results. Number of replicates $(n)$ varies between the parameters because 
Shannon index is only defined for species richness $\leq 1$ and evenness for species richness $\leq 2$.

Table 8 Summary of the GLM results for the dependence of number of individuals, number of species and Shannon index on vegetation cover per height classes in the two habitats, $p$-values printed in bold indicate significant results. Number of replicates $(n)$ varies between the parameters because Shannon index is only defined for species richness $\leq 1$ and evenness for species richness $\leq 2$. B-Coefficient denotes the slope of the regression.

Table 9 Summary of the GLM results for the dependence of numbers of individuals, species abundance and number of species, Shannon-index and evenness on different grazing intensities on different habitats (means \pm standard deviations), $p$-values printed in bold indicate significant results. Number of replicates $(n)$ varies between the parameters because Shannon index is only defined for species richness $\leq 1$ and evenness for species richness $\leq 2$.

Table 10 Summary of the linear regression results for the dependence of BMI and weight on vegetation cover per height classes, $p$-values printed in bold indicate significant results. $B$-Coefficient denotes the slope of the regression.

Table 11 Summary of GLM results for the dependence of removed seeds in different exclosure types on different weather data, $\mathrm{p}$-values printed in bold indicate significant results, $n=60$. B-Coefficient denotes the slope of the regression.

Table 12 Summary of GLM results for the dependence of the number of removed seeds on different habitat types in different exclosure types, $n=16$.

Table 13 Summary of linear regression of mean numbers of missing seeds on vegetation cover in different height classes in different exclosure types and on habitat type; $p$-values printed in bold indicate significant results. $B$-Coefficient is the raw regression coefficient; $n=8$.

Table 14 Summary of the GLM results showing the influence of grazing intensity on missing seeds (means \pm standard deviations) on loam and quartz, $p$-values printed in bold indicate significant results; $n=40$.

Table 15 Overview of missing seeds (mean of sums \pm standard deviation) for calculated predation of animal groups on different habitat types under different grazing intensities; $n=8$.

Table 16 Number of seedlings, plots and dung mass per grazing intensity..... 


\section{Appendices}

Appendix 1 GPS-data of the exclosure plots in chronological order. Reference system: WGS 84.

Appendix 2 GPS-data of the trapping plots in chronological order. Reference system: WGS 84.

Appendix 3 Shannon index, evenness, total number of individuals and total number of species, total and mean vegetation cover [\%] per trap plot, habitat, farm and grazing intensity. Shannon index is only defined for species richness $\leq 1$ and evenness for species richness $\leq 2$.

Appendix 4 Mean weather data and moon data per trap plot. IV

Appendix 5 Caught and measured Individuals of the striped mouse Rhabdomys pumilio. ..... V

Appendix 6 Caught and measured Individuals of the elephant shrew Macroscelides proboscideus.

Appendix 7 Overview of Spearman rank correlation results of weather data and day of year for the analyses of trapped small mammals.

Appendix 8 Overview of Spearman rank correlation results of weather data and day of year for the analyses of the missing seeds.

Appendix 9 Number of seedlings per family, taxa and grazing intensity. Points indicate no seedlings.

Appendix 10 Reddish-grey musk shrew Crocidura cyanea ................................................... VIII

Appendix 11 Bush Karoo Rat Otomys unisulcatus.............................................................. VIII

Appendix 12 Hairy-footed Gerbil Gerbillurus paeba. .......................................................... VIII

Appendix 13 Gerbil mouse Malacothrix typica................................................................ VIII

Appendix 14 Pygmy Mouse Mus minutoides. ................................................................... VIII

Appendix 15 Short-tailed Gerbil Desmodillus auricularis. .................................................. VIII

Appendix 16 Contents of electronic appendices. ................................................................... IX 


\section{Abstract}

In order to assist the management of the Knersvlakte Conservation Area with future management decisions, the interactions between wildlife and vegetation under different livestock grazing intensities and habitat types in the Knersvlakte, South Africa were investigated. The Knersvlakte belongs to the Succulent Karoo, which is a biodiversity hotspot due to its extraordinary plant species richness.

A total of 22 plots were selected according to two grazing intensities (moderate and intensive) and two major habitat types (quartz fields, loamy soils) were studied. On each of these plots, small mammal live trapping (90 traps during 4 nights) was carried out and the cover of different vegetation layers was estimated. Moreover, seed predation experiments with different exclosure types were carried out on a total of 8 plots to compare the activity of arthropods, small mammals and birds under different grazing intensities and in different habitats. In order to detect potentially confounding effects, abiotic factors including weather, moon, and day of year were determined from August to November 2007.

In total, 140 small mammal individuals from 10 species were caught during 7,920 trap nights. The small mammal species composition on intensively grazed fields was a subset of that on moderately grazed fields. The most abundant species on loam fields were Macroscelides proboscideus and Rhabdomys pumilio and on quartz fields Macroscelides proboscideus and Gerbillurus paeba. Generalised linear models revealed that habitat type had the strongest influence on abundance and diversity of small mammals. Vegetation cover only had an indirect influence on abundance, diversity and the body condition of small mammals via the habitat type. A high grazing intensity negatively influenced the seed predation of small mammals and arthropods (mainly ants and termites), which were the most important seed predators and consequently the most important analysed animal groups for vegetation dynamics. A germination experiment with dung of indigenous herbivores implicates that antelopes are more abundant on moderately grazed fields than on intensively grazed fields. Weather, moon, and day of year only influenced the seed predation of arthropods and small mammals.

Overall, a high grazing intensity had a negative influence on the diversity and activity of small mammals, indigenous herbivores and the activity of arthropods. From a conservation point of view, it would thus be desirable to reduce the livestock grazing intensity in the future Conservation Area

Keywords: Namaqualand, Macroscelides proboscideus, Rhabdomys pumilio, live trapping, species richness, exclosure, seed predation, vegetation cover, domestic livestock, biodiversity, nature conservation 


\section{Introduction}

The conservation of biodiversity is one of the most important challenges of our century. Basic ecological knowledge and a full understanding of determinants of biodiversity are essential to perform it (HOFFMAN et al. 2007). Conservation is particularly effective in hotspots of biodiversity, because many species can be protected here simultaneously in a relative small area (MEYERs et al. 2000). One of these biodiversity hotspots of global significance (COWling \& Hilton-TAYlor 1994) is the Succulent Karoo in southern Africa, which harbours an extraordinarily high number of plant species (DESMET \& COWLING 1999) with more than 3500 plant species of which $25 \%$ are endemic to the region (DESMET 2007). In Namaqualand, which is part of the Succulent Karoo, plant diversity is most commonly associated with quartzite gravel plains, which characterise certain areas there (HOFFMAN et al. 2007). An area deserving protection because of its high occurrence of quartz fields is the Knersvlakte, harbouring about 142 plant species ca. $70 \%$ of which are local or regional endemics (SCHMIEDEL \& JÜRGENS 1999). Each region within the Knersvlakte where quartz fields occur has its own quartz-field flora (SCHMIEDEL \& JÜRGENS 1999; SCHMIEDEL 2002). The quartz fields are famous for living stones, mainly Aizoaceae (SCHMIEDEL \& JÜRGENS 1999), small roundish plants which have adapted to the extreme environmental conditions of this semi-arid region.

Bioclimatic models suggest that the warming of air temperatures, which is projected to occur in the next 50 years, will have dire consequences for the biodiversity of Namaqualand (HOFFMAN et al. 2007). In addition to climate change effects, livestock farming, cropping, and invasion of alien plants threaten the fragile ecosystems of the Succulent Karoo (CONSERVATION INTERNATIONAL 2008; HOFFMAN et al. 2007). Livestock grazing in Namaqualand can be dated back 2,000 years ago (HoFFMAN et al. 2007). For 200 years of European settlement, much of the Succulent Karoo has been stocked with domestic small stock; indigenous large herbivores were consequently reduced in numbers and restricted to protected areas (DEAN \& MILTON 1999). Grazing management had further shaped the vegetation texture in the semi-arid Karoo in the last decades (MiLTON et al. 1992), which has a high influence on small mammals (AVERY 1993).

In many natural and man-made habitats of dry lands, rodents play an important ecological role (SCHLITTER 1978; HAPPOLD 2001). Large mammals are relatively rare in the Succulent Karoo, while small mammals (rodents and elephant shrews) are highly abundant herbivores 
and can reach extreme high population densities; consequently, they are of crucial importance within this ecosystem (SCHRADIN \& PILLAY 2005a). It is known from earlier studies that small herbivores are able to increase floral diversity by reducing interspecific competition (KERLEY 1992). Furthermore, small mammals act as pollinators for certain plant species in the Succulent Karoo (KLEIZEN et al. 2008), and are important for direct seed dispersal (KeRLEY et al. 1990). Research has shown that small herbivores (less than $5 \mathrm{~kg}$ ) can influence biomass and composition of the vegetation (FARMER \& MILTON 2006). They browse on similar species as domestic small stock, so their inclusion in the assessment of grazing capacity of natural rangeland is necessary, particularly in conservation areas (FARMER \& MILTON 2006). Desert rodent diversity can be correlated with the complexity of soil and vegetation structures (KERLEY 1992). In southern African, studies were carried out on rodent community structure (LINZEY \& KESNER 1997) and its ecological interactions (KERLEY 1992), impact of disturbances on diversity of rodents (FERREIRA \& VAN AARDE 1999), habitat occupancy patterns by rodents (NEL 1978), population dynamics of rodents (GLIWICZ 1985), and the role of rodents for seed dispersal and predation (KERLEY et al. 1990; KERLEY 1992). As rodent community characteristics have a potential to indicate ecological disturbances (AVENANT 2000), they were also used for the valuation of effects caused by grazing pressure (NYAKOLARTEY \& BAXTER 1995; BLAUM et al. 2007). It is not exactly known what effect habitat change caused by grazing has on small mammal communities, as research on the effect of different land use intensities on small mammal assemblages in South Africa are scarce (KERLEY 1992).

Agricultural practices, such as overgrazing, have intensified the degradation of the soil and vegetation and led to a rapid decline of biodiversity (DARKOH 2002). An appropriate management of southern African rangelands can maintain biodiversity in the drylands. There is need to assess the agricultural potential of the semi-arid environments and develop specific agricultural policies or programmes to enhance their sustainable utilisation and conservation of biodiversity (DARKOH 2002).

The Knersvlakte has often been recognized as a priority region for plant conservation (Hilton TAylor \& Le Roux 1989, Hilton TAYlor 1994, Lombard et al. 1999). CapeNature implements a Conservation Area in the Knersvlakte, which is defined in "South Africa's national biodiversity strategy and action plan" of the DEPARTMENT OF ENVIRONMENTAL AFFAIRS \& TOURISM (2005) as a "geographically defined area where 
conservation of important biodiversity is needed in order to ensure sustainable benefits“. The results of my study shall provide a basis to assist the management of the Knersvlakte Conservation Area with future management decisions.

The aim of this study was to investigate the activity and diversity of small mammals. The functional role of small mammals and other wildlife in the Knersvlakte regarding seed predation and seed dispersal was examined and it was assessed how this is affected by domestic livestock, habitat type and vegetation cover (Figure 1).

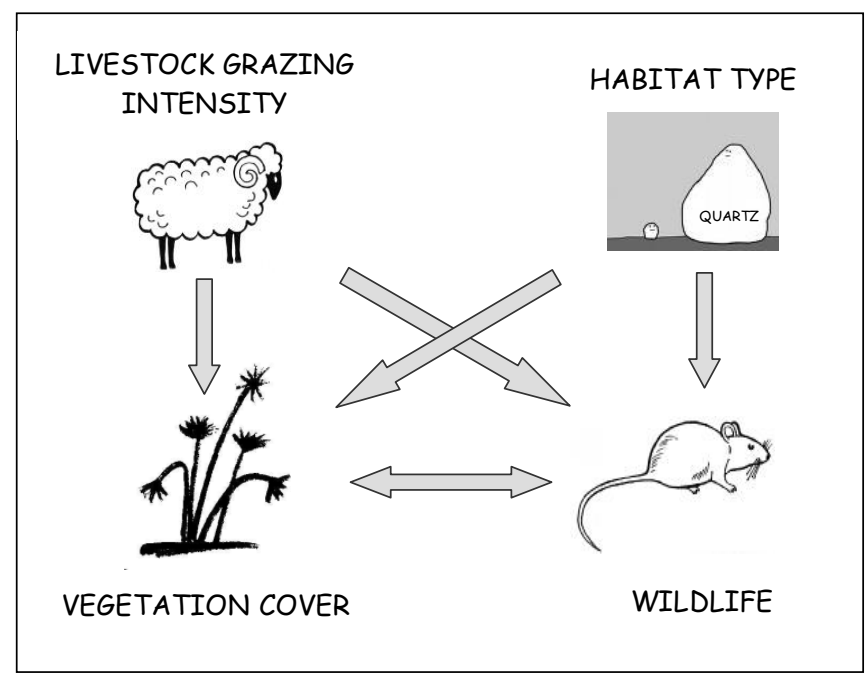

Figure 1 Schematic graph showing the analysed interactions between wildlife, vegetation cover, livestock grazing intensity and habitat type.

Specifically, the following research questions were asked:

- Do domestic livestock grazing intensity, habitat type, and vegetation cover influence diversity, activity (e.g. foraging and seed predation), BMI (body mass index) and body weight of small mammals?

- Do domestic livestock grazing intensity, habitat type, and vegetation cover affect two major dietary guilds of small mammals (i.e. insectivores and omnivores) in different ways?

- What is the role of small mammals and other wildlife for the vegetation, regarding seed predation and dispersal? 


\section{Material and methods}

\subsection{Study area}

The study was conducted from August to November 2007 in the Knersvlakte $\left(30^{\circ} 27^{\prime}\right.$ $\left.32^{\circ} 05^{\prime} \mathrm{S}, 17^{\circ} 46^{\prime}-19^{\circ} 06^{\prime} \mathrm{E}\right)$. The Knersvlakte is situated in southern Namaqualand, which is part of the Succulent Karoo biome in the Western Cape Province of South Africa (DESMET 2007) (Figure 2). The region is famous for its multitude of blooming plants during the flowering season (August- October).

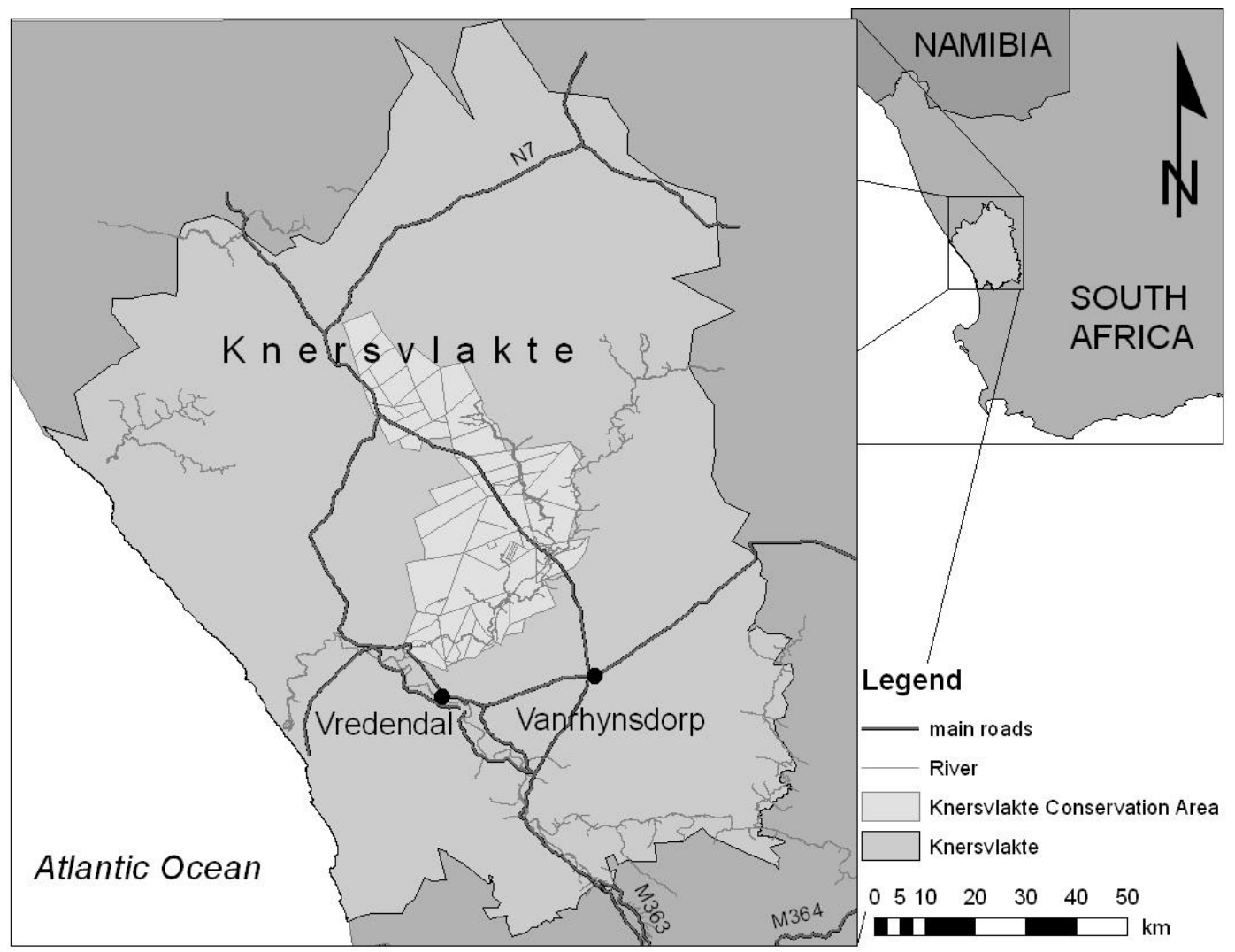

Figure 2 Location of the Knersvlakte in the western part of South Africa. The study area is located in the projected Knersvlakte Conservation Area.

At present, 3500 vascular plant species have been recorded in Namaqualand. Approximately $25 \%$ of these species are recognised as endemic (DESMET 2007). This level of diversity and endemism is exceptionally high, especially for a desert region (DESMET \& COWLING 1999). The Succulent Karoo is one of 25 global biodiversity hotspots and one of only two internationally recognised desert regions, besides the Horn of Africa (MYERS et al. 2000; DESMET 2007). The vegetation of the Succulent Karoo biome is dominated by small leaf succulent chamaephytes (MiLton et al. 1997); it is the world's richest succulent flora (LOMBARD et al. 1999). 
The Knersvlakte is characterised by the frequent occurrence of a special habitat type, the socalled quartz fields (SCHMIEDEL \& JÜRGENS 1999). The quartz fields are areas where gravellike quartz stones cover the soil surface. The quartz fields are highly patchy and alternate with loamy soil surface. Dwarf, compact leaf-succulents, typically dominate quartz fields whereas more fruticose, leaf succulent growth forms dominate loamy soils. In the following, these two habitat types are referred to as quartz and loam. The most abundant vascular plant families are Aizoaceae (Schmiedel \& JÜRgENS 1999) and Asteraceae (Milton et al. 1997).

The Knersvlakte is a winter-rainfall region (May to September) (RUTHERFORD \& WESTFALL 1986; MiLton et al. 1997) with a mean annual rainfall of $116 \mathrm{~mm}$ (MUCINA et al. 2006). Water supply is occasionally supplemented by fog and dew (MUCINA et al. 2006). Climate is relatively mild (COWLING et al. 1999), with temperatures ranging from below zero during winter months to above $37{ }^{\circ} \mathrm{C}$ during summer (MACKELlar et al. 2007; SiMONS \& ALLSOPP 2007) with an annual average of $16-18^{\circ} \mathrm{C}$ (CowLING et al. 1997).

From the late $17^{\text {th }}$ until the end of the $18^{\text {th }}$ century, few grazing ungulates were reported by early travellers (HOFFMAN \& RHODE 2007) although elephants, zebras and small antelopes appear to have been relatively common (HOFFMAN et al. 2007).

Until the $18^{\text {th }}$ century, the Knersvlakte was inhabited by the indigenous !Khoikhoi people who lived as herders and hunters (ROHDE et al.2007). For the past 200 years, the Knersvlakte has been used for commercial small stock farming (sheep and goat) by farmers of European origin. However, the land has a very low grazing capacity and agricultural potential (DESMET 2007). The recommended stocking rate is between 8 and 12 ha per small stock unit (ha/SSU) (personal communication Department of Agriculture, Vredendal Office).

Today, the Knersvlakte is still predominantly used for commercial small stock farming (HOFFMAN et al. 2007). A decline in livestock numbers in the last 50 years goes hand in hand with an increase in conservation initiatives (HOFFMAN \& RHODE 2007). Since 2007, the Department of Nature Conservation of the Western Cape Province (CapeNature) has been projecting the setup of the Knersvlakte Conservation Area (Elbé Cloete, personal communication 2008) (Figure 2), located in the quartz field area with its high occurrence of endemic plants.

\subsection{Description of the farms}

For the study, I selected farms with a high frequency of quartz fields and varying grazing intensities that are situated in the Knersvlakte Conservation Area. Fieldwork was carried out on the farms Quaggaskop, Ratelgat, Hoogstaan and Rooiberg. They are located next to the 
national route N7, approximately 20-60 km northwest of Vanrhynsdorp (Figure 3) and approximately $60-80 \mathrm{~km}$ east of the Atlantic Ocean $\left(31^{\circ} 24^{\prime} \mathrm{S}, 18^{\circ} 30^{\prime} \mathrm{N}\right)$.

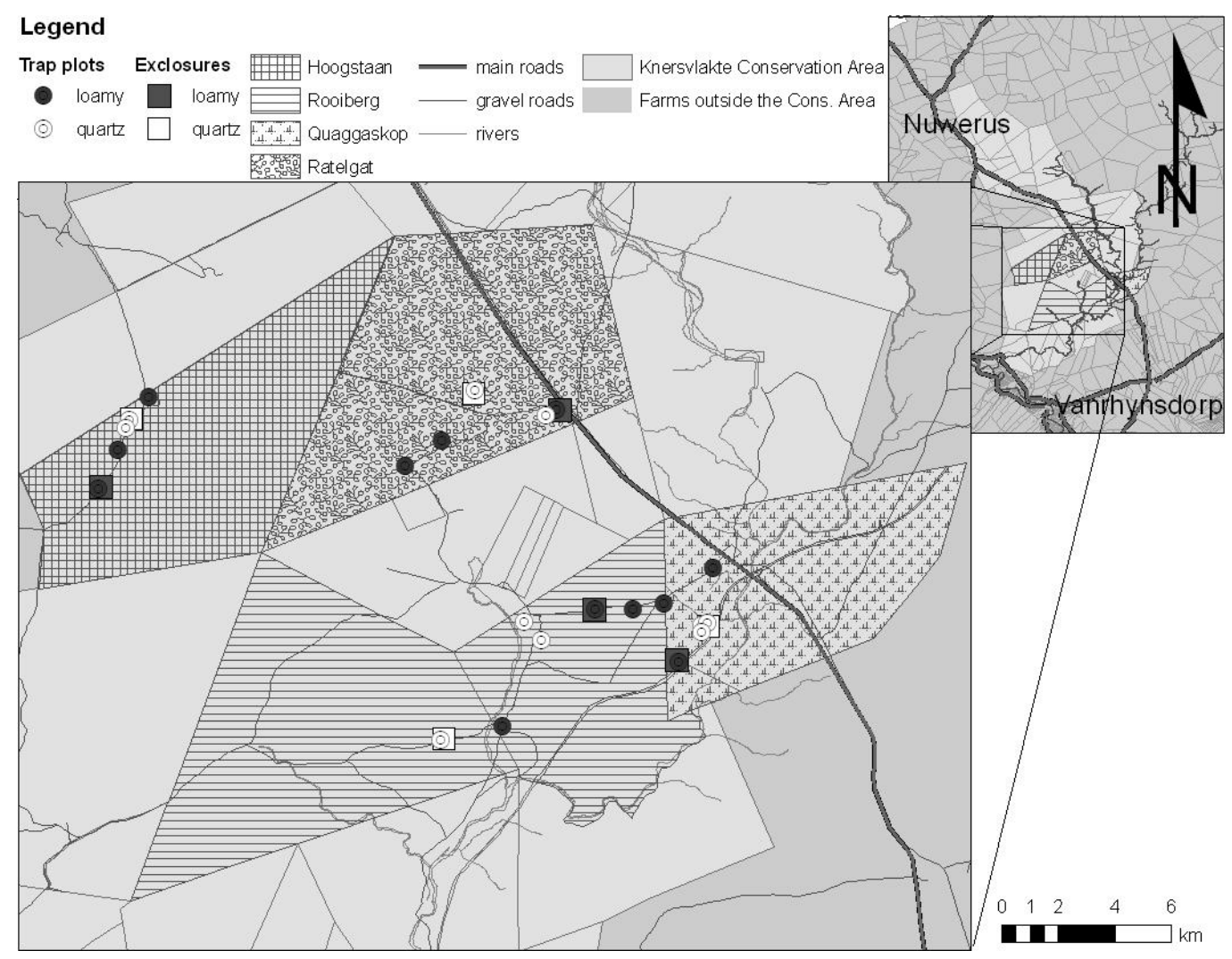

Figure 3 Scale of the Knersvlakte Conservation Area (Figure 2) and the investigated farms, trap plots and exclosures in detail. CapeNature provided all GIS layers except for the plot locations.

The sampling on Quaggaskop was conducted on a section of the farm of 1,500 ha in size, which has been excluded from grazing for about 40 years (Figure 3). This part of Quaggaskop has a high frequency of quartz fields and is used for tourism with hiking trails and informative signboards for some of its succulent plants.

Ratelgat (7,062 ha) is moderately grazed by sheep, goats and a small number of donkeys (17 ha/SSU; the small stock units on the farms were calculated according to ESLER et al. (2006)). The donkeys are kept to protect small livestock against predators such as jackals. For the last eight years, the management regime has been extensive rotational grazing and the other source of earning has been tourism. Before that, the land had not been used for livestock grazing for several years.

Hoogstaan (5,950 ha) has the highest proportion of rocky hills among the farms and is subject to heavy grazing with sheep and goats (10 ha/SSU). It is privately owned and has been used for farming for at least eighteen years. 
Rooiberg is the largest of the investigated farms with 11,506 ha. However, merely two thirds of the farm are subject to grazing and SSU were calculated on a 7,000 ha basis only (Elbé Cloete, personal communication 2007).With 12 ha/SSU Rooiberg is, like Hoogstaan, a heavily grazed farm. The farm is located on public land, which has been farmed by various farmers for twenty years. Before that, the land was used by the military and for mining. Consequently, much of the landscape is in a highly degraded state. In this study, I refer to Quaggaskop, Ratelgat as moderately grazed, and Hoogstaan and Rooiberg as intensively grazed farms (Figure 3).

\subsection{Small mammal life trapping}

To analyse the influence of grazing intensity and habitat type on the activity, BMI and body weight as well as the species composition of small mammals, I trapped small mammals on farms with different grazing intensities and different habitats.

The trapping plots were installed on four farms (Figure 3). Trapping was performed on 22 plots (GPS coordinates cf. Appendix 1) with visually homogenous vegetation in comparable habitat types. For logistical reasons, most of the plots were located at a $10 \mathrm{~m}$ distance to the gravel roads on the farmland (Figure 3). Ten plots were positioned on quartz fields and twelve plots on loamy fields. In each case, one half was subject to moderate grazing pressure and the other half was heavily grazed. In every plot of 2.025 ha in size, 90 Sherman ${ }^{\circledR}$ - life traps were placed $15 \mathrm{~m}$ apart, in ten lines with nine traps each. As suggested and based on previous experiences made by Cornelia B. Krug (University of Stellenbosch), small traps (15 cm long $\times 4.5 \mathrm{~cm}$ wide $\times 5 \mathrm{~cm}$ high $)$ and big traps $(25 \mathrm{~cm} \times 8 \mathrm{~cm} \times 9 \mathrm{~cm})$ were put up alternately. Different sizes of traps were used to cover a wide range of species. The vents were placed randomly. Each trap contained cut straw for thermal insulation and was baited with a mixture of peanut butter and oat flakes (after BEER 1964; PATRIC 1970; KRUG 2002). Moreover, the traps contained a small piece of apple against dehydration.

On each plot, the traps were installed for four consecutive nights. The traps were opened at 6 pm and checked at 7 am the next morning for a total of 88 nights. This time was chosen in order to increase the probability of trapping diurnal as well as the nocturnal animals. The trapped small mammal species were determined using a field guide (STUART 2001) and the expertise of Cornelia B. Krug. A piece of fur in the neck was cut to mark individuals and to recognise recaptures. Weight measurements (recorded to nearest gram using a Pesola spring balance scale), body length, tail length, tarsus length, and sex were noted, as well as recaptures. Morphometric measures were taken on anaesthetised animals. Straw and bait were 
removed and replaced after every trapping to reduce potential odour-induced biases occurring in subsequent trapping plots, as described by BoONSTRA \& KREBS (1976) and DRICKAMER (1995).

\subsection{Seed predation experiment}

To analyse the influence of grazing intensity and habitat type on wildlife activity with regard to seed predation and dispersal, I arranged exclosures on farms with different grazing intensities and different habitats. These exclosures are made up of different types of cages to exclude certain animals from the laid-out seeds (DAUSMANN et al. 2008; SPEHN \& GANZHORN 2000).

The exclosures were set up in eight plots, two on quartz fields with moderate grazing, two on intensively grazed quartz fields, two on loamy soil with moderate grazing and two on loamy soil with an intensive grazing intensity (Figure 3, for GPS coordinates see Appendix 2). On each plot, 20 exclosures and 10 controls were arranged alternately in three parallel lines (10 exclosures per line) with a distance of $15 \mathrm{~m}$ in between.

The first type (in the following referred to as "impermeable") consisted of cages (40 cm long $\times 30 \mathrm{~cm}$ wide $\times 10 \mathrm{~cm}$ high) made from netting wire with a mesh width of $1.5 \mathrm{~cm} \times 1.5 \mathrm{~cm}$ aimed at investigating arthropods activity (mainly insects e.g. ants and termites). The second type (in the following referred to as "permeable") consisted of cages of equal size $(40 \mathrm{~cm} \times$ $30 \mathrm{~cm} \times 10 \mathrm{~cm}$ ), but with openings on the two opposing longer sides to allow small mammals to enter. The control plots did not feature a cage (in the following referred to as "control") aimed at investigating birds activity. In all cases, a piece of linen $(40 \mathrm{~cm} \times 30 \mathrm{~cm})$ was used as an underlayment. To attract a wide range of species in this experiment, five different types of seed (sweet corn, flax seeds, rapeseeds, sunflower seeds and sesame seeds) were selected. The seeds were arranged in five lines of 10 seeds per line grouped by seed type, so that every exclosure contained a total of 50 seeds. The number of seeds was controlled and refilled every day for 32 days.

\subsection{Vegetation data}

To analyse the influence of grazing intensity and habitat on the vegetation, and the influence of the vegetation on wildlife activity, I determined the vegetation cover surrounding the traps and exclosures. The horizontal vegetation cover was estimated to the nearest percent for three 
different height levels $(<15 \mathrm{~cm} ; 15-30 \mathrm{~cm} ;>30 \mathrm{~cm})$ within a $1 \mathrm{~m} \times 1 \mathrm{~m}$ square around every trap and $2 \mathrm{~m} \times 2 \mathrm{~m}$ around every exclosure.

\subsection{Germination experiment}

To analyse the influence of indigenous herbivores on the vegetation with respect to seed predation and dispersal via endozoochory under different grazing intensities and on different habitat types, I conducted a germination experiment with dung of indigenous herbivores. For this purpose, I collected dung of indigenous herbivores such as Springbok (Antidorcas marsupialis), Duiker (Cephalophus monticola), Steenbok (Raphicerus campestris) and Cape hare (Lepus capensis), which were the most abundant indigenous herbivores in the study area (personal observations). I differentiated dung of domestic livestock and dung of wildlife after a field guide of STUART \& STUART (1994).

Dung samples of indigenous herbivores were collected on those plots where dung was available. I searched every plot for dung with the same effort. A maximum of $10 \mathrm{~g}$ air-dried dung of each plot was elutriated in glass bottles in the laboratory with $50 \mathrm{ml}$ tap water for 24 hours. The dung-water suspensions were poured on sterilised potting soil with a 1:1 volume ratio of sand and peat in a plant pot $(10 \mathrm{~cm}$ high $\times 10 \mathrm{~cm}$ long $\times 10 \mathrm{~cm}$ wide $)$. To induce seed germination under controlled conditions, the plant pots were placed in the greenhouse at the University of Hamburg. They were irrigated three times a day and kept at a temperature between 25 and $40{ }^{\circ} \mathrm{C}$. For four months, the seedlings were repot and cultivated until they could be identified. Species were determined using a field guide (LE ROUX 2005) and by expert knowledge (Ute Schmiedel, University of Hamburg).

\subsection{Weather data, moon size and day of year}

For understanding the interrelations between small mammals and their habitat, different environmental features were measured. The weather data was derived from the Moedverloren BIOTA computer controlled weather station, situated approximately $10 \mathrm{~km}$ from Rooiberg and Hoogstaan. The weather parameters and moon data used for the analysis in this study were air temperature $\left({ }^{\circ} \mathrm{C}\right)$, relative humidity of the air $(\%)$, leaf wetness $(\%)$, rainfall $(\mathrm{mm})$, waning and waxing moon (in categories: 1-15) and moon size (in categories: 1-15). The mean values of these variables for every trapping night were calculated for the time between $6 \mathrm{pm}$ and $7 \mathrm{am}(13 \mathrm{~h})$ or $3 \mathrm{pm}$ to $3 \mathrm{pm}(24 \mathrm{~h})$. Furthermore, the mean of all abiotic parameters (weather data), day of year (number of days counted since the beginning of the year), as well as the moon data were noted for each plot. 


\subsection{Statistical Analyses}

For the statistical analyses the computer program STATISTICA 8.0 (STATSOFT, INC. 2007) was used. First, histograms for all data were visually checked for normal distribution and boxwhisker plots were visually checked for homogeneity of variances. When the data were normally distributed, ANOVAs were used to check several differences of different variables at the same time. When the data were not normal distributed generalised linear models, (GLMs) were used. GLMs with log-link and a Poisson distribution were used for count data to establish a relationship between several variables (QUINN \& KEOUGH 2002). To account the data had no perfect Poisson distribution I used "Over dispersion; Pearson Chi" (GARDNER et al. 1995). A chi ${ }^{2}$-test was used to compare observed and expected frequencies in categories (see QUINN \& KEOUGH 2002). Linear regressions were used to analyse the influences of the vegetation cover in three different height classes and to verify a regression between the vegetation cover and the different variables. Maps were produced with Arc GIS 9.3.

\section{Small mammal live trapping}

All statistical analyses on trapped individuals were done without recaptures. Species richness was calculated by counting the number of species captured per plot, while species abundances were quantified as total number of individuals captured per species per plot. Additionally for species diversity calculations Shannon index (Hs) and evenness was chosen and calculated per plot. Trapping success was calculated as the number of captured individuals / 100 trap nights. The physical condition of small mammals was expressed by a body-mass-index (BMI). As BMI, I used the quotient of weight [g] and tarsus length [mm].

\section{$\underline{\text { Vegetation data }}$}

For the analyses, vegetation cover values were averaged at plot level. To calculate the total vegetation cover, the covers of all three different height classes were summed.

\section{$\underline{\text { Seed predation experiment }}$}

For the statistical analyses, first the number of missing seeds per day, was counted. Then, the means of the sums per exclosure type were calculated. In the following, this value is called "mean of sums". Seed predation was calculated by counting the removed seeds. To focus the analysis on certain animal groups (e.g. birds, mammals), differences of missing seeds (mean 
of sums) between different exclosure types were calculated. The calculated missing seeds of each animal group were tested with an ANOVA against each other.

When birds were assumed preying on the seeds the group is referred to as "bird predation" in the following. When mainly small mammals were assumed preying on the seeds this group is in the following referred to as "small mammal predation". When mainly animals smaller then $2.5 \mathrm{~cm}$ by $2.5 \mathrm{~cm}$ preyed on the seeds this group is in the following referred to as "arthropod predation".

$$
\begin{array}{lll}
\text { Control }- \text { permeable } & = & \text { bird predation } \\
\text { Permeable }- \text { impermeable } & = & \text { small mammal predation } \\
\text { Impermeable } & = & \text { arthropod predation }
\end{array}
$$

\section{Weather data, moon size and day of year}

Some weather data (temperature, relative humidity of the air, leaf wetness, rain) as well as moon data (waning and waxing moon, size of moon) and day of year were tested on their influence, to reduce the transient effect of environmental impact. For the trapping statistics, means of hourly weather data and daily moon data for every night (13 h; 6pm-7am) were calculated. For the exclosure statistics, a mean of hourly weather data and daily moon data for every day ( $24 \mathrm{~h} ; 3 \mathrm{pm}-2 \mathrm{pm})$ were calculated. The size of moon was included to reflect the moon brightness. 


\section{Results}

\subsection{Vegetation structure}

\section{Habitat type}

The mean vegetation cover around the traps was generally lower than $18 \%$ and differed between the two habitat types. Vegetation cover in all three defined height classes and in total was about two times higher on loam than on quartz and decreased in both habitats with increasing vegetation height (Table 1).

Table 1 Summary of the ANOVA results for the dependence of vegetation cover [\%] around the traps $\left(1 \mathrm{~m}^{2}\right)$ on habitat type in different height classes (mean \pm standard deviation); $p$-values printed in bold indicate significant results; loam $n=12$, quartz $n=10$.

\begin{tabular}{cccc}
\hline Height classes & Loam & Quartz & $\boldsymbol{p}$-value \\
\hline$<\mathbf{1 5} \mathbf{~ c m}$ & $8.5 \pm 3.3$ & $5.4 \pm 2.9$ & $\mathbf{0 . 0 3 0}$ \\
$\mathbf{1 5} \mathbf{- 3 0} \mathbf{~ c m}$ & $5.8 \pm 1.5$ & $3.2 \pm 2.5$ & $\mathbf{0 . 0 0 7}$ \\
$>\mathbf{3 0} \mathbf{~ c m}$ & $3.1 \pm 2.4$ & $1.3 \pm 1.0$ & $\mathbf{0 . 0 4 1}$ \\
Total cover & $17.4 \pm 3.7$ & $9.9 \pm 5.9$ & $\mathbf{0 . 0 0 1}$ \\
\hline
\end{tabular}

Similar to the traps, the total vegetation cover and the vegetation cover for all three height classes around the exclosures was higher on loam than on quartz. However, this difference was not significant for the lowest height class (Table 2).

Table 2 Summary of ANOVA results for the dependence of vegetation cover [\%] around the exclosures $\left(4 \mathrm{~m}^{2}\right)$ on habitat type in different height classes (mean \pm standard deviation); $p$-values printed in bold indicate significant results; loam $n=120$, quartz $n=120$.

\begin{tabular}{cccc}
\hline Height classes & Loam & Quartz & $\boldsymbol{p}$-value \\
\hline$<\mathbf{1 5} \mathbf{~ c m}$ & $8.1 \pm 4.2$ & $6.7 \pm 2.1$ & 0.576 \\
$\mathbf{1 5} \mathbf{- 3 0} \mathbf{~ c m}$ & $10.7 \pm 5.1$ & $2.0 \pm 1.7$ & $\mathbf{0 . 0 1 7}$ \\
$>\mathbf{3 0} \mathbf{~ c m}$ & $7.0 \pm 4.3$ & $0.6 \pm 0.8$ & $\mathbf{0 . 0 2 8}$ \\
Total cover & $25.7 \pm 9.8$ & $9.21 \pm 2.64$ & $\mathbf{0 . 0 1 8}$ \\
\hline
\end{tabular}

Because of the high structural difference between the two habitat types, I treated them separately in the subsequent analyses, where possible.

\section{Grazing intensity}

Total vegetation cover was nearly the same on quartz and loam for both grazing intensities (Table 3). In both habitat types, the vegetation cover in the first height class was denser on moderately grazed plots than on intensively grazed plots. The opposite trend was found in the highest height class on loam and in the medium height class on quartz. However, these trends were not significant for the vegetation cover, neither on loam nor on quartz (Table 3). 
Table 3 Summary of the ANOVA results for the dependence of vegetation cover [\%] around the traps $\left(1 \mathrm{~m}^{2}\right)$ with different grazing intensities in different heights in the two habitat types (mean \pm standard deviation), (pvalues).

\begin{tabular}{|c|c|c|c|c|c|c|}
\hline \multirow{2}{*}{ Height classes } & \multicolumn{3}{|c|}{ Loam $(n=12)$} & \multicolumn{3}{|c|}{ Quartz $(n=10)$} \\
\hline & Moderate $(n=6)$ & Intensive $(n=6)$ & $p$-value & Moderate $(n=5)$ & Intensive $(n=5)$ & $p$-value \\
\hline$<15 \mathrm{~cm}$ & $9.5 \pm 3.0$ & $7.5 \pm 3.5$ & 0.319 & $5.8 \pm 3.1$ & $4.9 \pm 3.0$ & 0.674 \\
\hline $15-30 \mathrm{~cm}$ & $5.8 \pm 1.9$ & $5.8 \pm 1.2$ & 0.989 & $3.0 \pm 2.9$ & $3.4 \pm 2.3$ & 0.830 \\
\hline$>30 \mathrm{~cm}$ & $2.1 \pm 2.0$ & $4.1 \pm 2.4$ & 0.149 & $1.3 \pm 1.1$ & $1.3 \pm 1.0$ & 0.975 \\
\hline Total cover & $17.4 \pm 7.4$ & $17.4 \pm 2.6$ & 0.997 & $10.2 \pm 7.1$ & $9.7 \pm 5.2$ & 0.909 \\
\hline
\end{tabular}

\subsection{Species composition of small mammals}

In the following, I give a short description of the trapped species. I describe the two species I analysed separately in more in detail. The other trapped species are briefly described in a table (Table 4, Picture: see Appendix 10-15).

\section{$\underline{\text { Round-eared elephant shrew Macroscelides proboscideus (Shaw 1800) }}$}

The appearance of the round-eared elephant shrew is roundish with long legs and a long nose (Figure 4). The mean total length is $23 \mathrm{~cm}$ whereof the tail is about $12 \mathrm{~cm}$ long. The mass is 31-47 g (STUART 2001). Macroscelides proboscideus is endemic to South Africa. Roundeared elephant shrews are nocturnal as well as diurnal (APPS 2008). Despite the presence of a functional caecum, many authors still describe elephant-shrews as largely insectivorous (GRAHAM et al. 2008; NOWAK \& PARADISO 1983; SMITHERS 1983), although plant matter makes up almost a part of the diet and ancestral forms were herbivorous (GRAHAM et al. 2008). They feed on insects (77\%) with a preference for ants and termites (STUART 2001), green vegetation, berries, fruits and sometimes lizard eggs (ApPs 2008). The diet varies seasonally, with the intake of herbage peaking in winter, when herbage may comprise up to $97 \%$ of the diet. When food is limited, they respond with torpor (LOVEGROVE 1999). They are monogamous and male and female individuals have the same size in home ranges (GRAHAM et al. 2008).
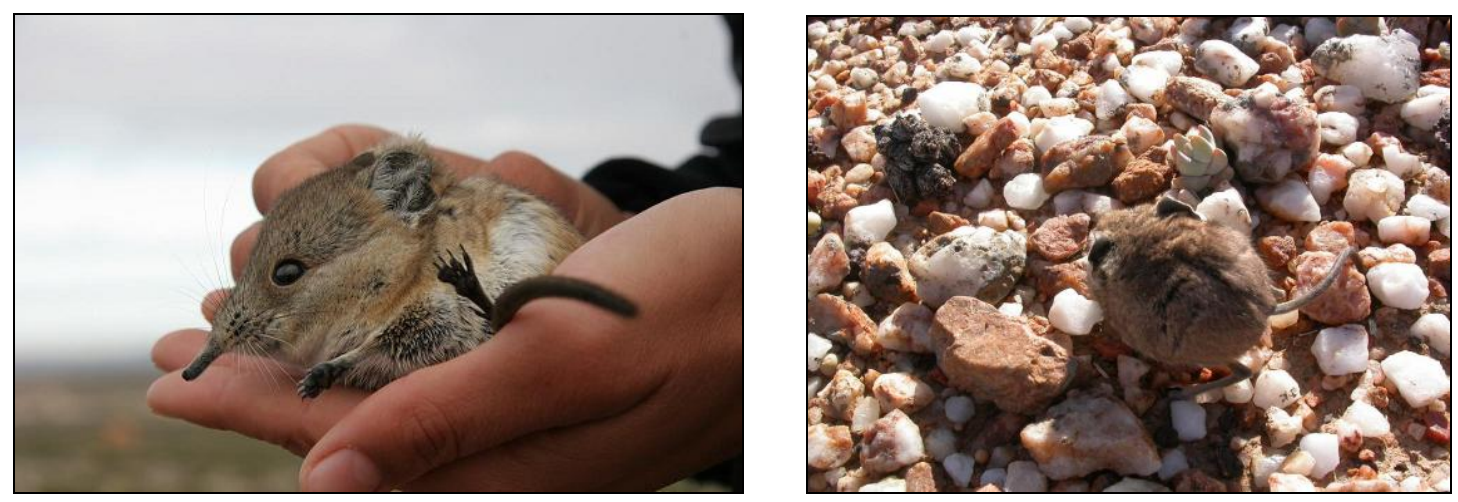

Figure 4 Side-face (left picture) and view from above (right picture) of the round-eared elephant shrew Macroscelides proboscideus. 


\section{$\underline{\text { Four-striped grass mouse Rhabdomys pumilio (Sparman 1784) }}$}

The appearance of the striped mouse is longish with a mean length of $18-21 \mathrm{~cm}$ whereof the tail is $8-11 \mathrm{~cm}$ long and the mass is $30-55 \mathrm{~g}$ (STUART 2001) and with four stripes on the back. Rhabdomys pumilio is native to South Africa (Figure 5). The striped mouse is diurnal. Rhabdomys pumilio is omnivore and feed on green vegetation, insects and seeds; sometimes the animals are cannibalistic. For some plant species, they are important pollinators (APPS 2008). Rhabdomys is a group-living solitary forager with communal breeding and helpers at the nest (Schradin \& PILlay 2006). They show one of the most complex social systems found in rodents (SCHRADIN 2008). The social behaviour of Rhabdomys in the Succulent Karoo is in great contrast to the social system of the same species in moist grasslands, where it is solitary (ChOATE 1972; WiLlan \& MeESTER 1989; Schradin 2005; Schradin and PILlay 2005). Accordingly, to Schradin \& PIllay (2006) 151 mice/hectare occur in semiarid regions, several more than in grasslands. For small mammals, living in groups could be a strategy that provides some benefits in arid environments (DEAN \& MiLTON, 1999).

During their active time in the morning and in the afternoon Rhabdomys pumilio, cover a distance of more then $900 \mathrm{~m} /$ day. The rest of the day, they hide in the vegetation. Female Rhabdomys have their own territories, which they aggressively defend against other females; male territories overlap a number of female territories (WILLAN \& MEESTER, 1989; SCHRADIN \& PILlay, 2006).
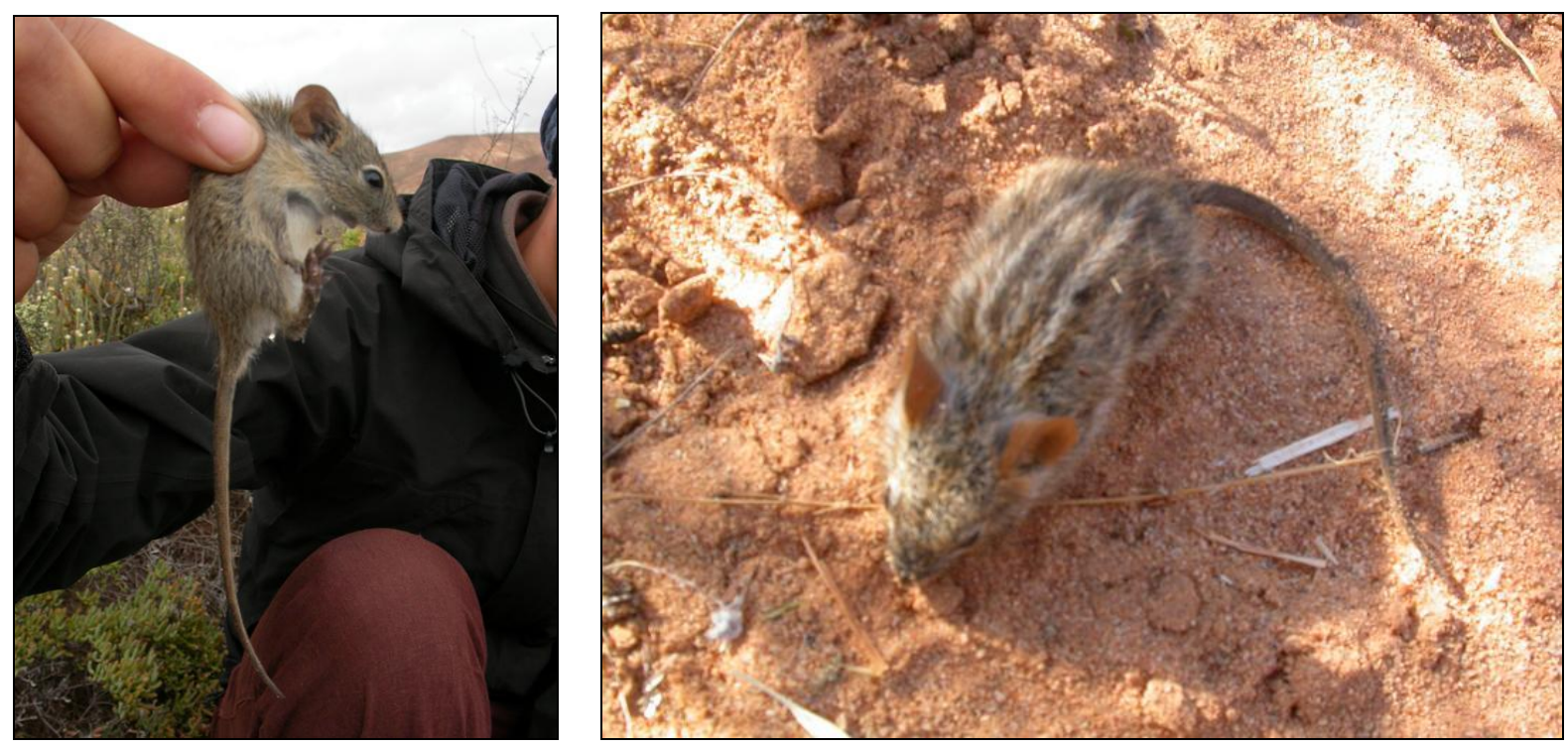

Figure 5 Side-face (left picture) and view from above (right picture) of the four-striped grass mouse Rhabdomys pumilio. 
Table 4 Overview of trapped species and food preference, distribution and behaviour.

\begin{tabular}{|c|c|c|c|c|c|}
\hline Species & Mean weight & Food & Distribution & Behaviour & References \\
\hline $\begin{array}{l}\text { Aethomys } \\
\text { namaquensis }\end{array}$ & $55 \mathrm{~g}$ & herbivore & Southern Africa & nocturnal & Снімімва et al. 1999 \\
\hline $\begin{array}{l}\text { Crocidura } \\
\text { cyanea }\end{array}$ & $9 \mathrm{~g}$ & $\begin{array}{c}\text { insectivor } \\
\mathrm{e}\end{array}$ & South Africa & $\begin{array}{l}\text { diurnal und } \\
\text { nocturnal }\end{array}$ & $\begin{array}{l}\text { DE GRAAFF } 1981, \\
\text { SKINNER \& SMITHERS } \\
1990\end{array}$ \\
\hline $\begin{array}{l}\text { Desmodillus } \\
\text { auricularis }\end{array}$ & $50 \mathrm{~g}$ & granivore & $\begin{array}{l}\text { South African endemic species, south } \\
\text { west arid zone and prefers open } \\
\text { country with grass or karroid bushes as } \\
\text { cover }\end{array}$ & $\begin{array}{l}\text { nocturnal, } \\
\text { semi-social }\end{array}$ & $\begin{array}{l}\text { DOWNS et al. } 1994, \\
\text { DE GRAAFF } 1981, \\
\text { SKINNER \& SMITHERS } \\
1990\end{array}$ \\
\hline $\begin{array}{l}\text { Gerbillurus } \\
\text { paeba }\end{array}$ & $25 \mathrm{~g}$ & omnivore & $\begin{array}{l}\text { South African endemic, arid and semi- } \\
\text { arid areas of southern Africa, prefer } \\
\text { open habitats with low shrub cover }\end{array}$ & $\begin{array}{l}\text { nocturnal, } \\
\text { social } \\
\text { tolerance }\end{array}$ & $\begin{array}{l}\text { WHITE } \text { et al. } 1997, \\
\text { NEL 1975, GRIFFIN 1990, } \\
\text { SKINNER \& CHIMIMBA } \\
2005\end{array}$ \\
\hline $\begin{array}{l}\text { Malacothrix } \\
\text { typica }\end{array}$ & $16 \mathrm{~g}$ & omnivore & Southern Africa & nocturnal & $\begin{array}{l}\text { DE GRAAFF 1981, } \\
\text { SKINNER \& SMITHERS } \\
1990\end{array}$ \\
\hline $\begin{array}{l}\text { Mus } \\
\text { minutoides }\end{array}$ & $6-8 \mathrm{~g}$ & omnivore & Southern and east Africa & $\begin{array}{l}\text { nocturnal, } \\
\text { monogamic }\end{array}$ & $\begin{array}{l}\text { SKINNER \& SMITHERS } \\
1990\end{array}$ \\
\hline $\begin{array}{l}\text { Myomyscus } \\
\text { verreauxii }\end{array}$ & $44 \mathrm{~g}$ & omnivore & South African endemic species & nocturnal & $\begin{array}{l}\text { DE GRAAFF } 1981, \\
\text { SKINNER \& SMITHERS } \\
1990\end{array}$ \\
\hline $\begin{array}{l}\text { Otomys } \\
\text { unisulcatus }\end{array}$ & $70-135 \mathrm{~g}$ & herbivore & $\begin{array}{c}\text { Southern African endemic, semi-arid } \\
\text { Karoo region of the south west arid } \\
\text { zone }\end{array}$ & $\begin{array}{c}\text { diurnal and } \\
\text { nocturnal }\end{array}$ & $\begin{array}{l}\text { BROWN \& WILLAN 1991, } \\
\text { PILLAY } 2000\end{array}$ \\
\hline
\end{tabular}

\section{$\underline{\text { Trapping success }}$}

During 7,920 trap nights (90 traps $\times 88$ nights), a total of 140 individuals of small mammals were caught. Overall, this corresponds to a trapping success of $1.77 \% \pm 2.96 \%$ SD $(n=22)$. Additionally, 45 recaptures occurred; the recapture rate thus was $24 \%$.

The habitat type significantly influenced the trapping success (GLM; $n=22, p=0.041$ ), with a higher trapping success on loam than on quartz, while grazing intensity had no significant influence on the trapping success in both habitats (Table 5). The trapping success (without recaptures) on loam was twice as high on intensively grazed plots as on moderately grazed plots. On quartz plots, the trapping success was equal under both grazing intensities (Table 5).

Table 5 Trapping success [\%] (mean \pm standard deviation) for different grazing intensities in the two habitat types, ( $p$-values).

\begin{tabular}{ccccccc}
\hline \multicolumn{2}{c}{ loam $(n=12)$} & & \multicolumn{3}{c}{ quartz $(n=10)$} \\
\cline { 1 - 1 } moderate $(n=6)$ & intensive $(n=6)$ & $p$-value & & moderate $(n=5)$ & intensive $(n=5)$ & $p$-value \\
\hline $1.9 \pm 2.2$ & $3.6 \pm 4.9$ & 0.450 & & $0.6 \pm 0.7$ & $0.6 \pm 0.9$ & 1.000 \\
\hline
\end{tabular}

Overall, 10 different small mammal species were identified, while one individual escaped and could not be determined (Table 6). Species of four different families were caught: Muridae (true mice and rats, gerbils, spiny mice, crested rat) was the most abundant family, with seven species. Together with the family Nesomyidae (climbing mice, rock mice, white-tailed rat, Malagasy rats and mice), with one determined species, they belong to the order Rodentia (rodents). The family Soricidae (shrews), with one caught species, belong to the order 
Eulipotyphla (formerly Insectivora). The family Macroscelididae (elephant shrews), with one caught species, belongs to the order Macroscelidea (elephant shrews). Most Rodentia species are herbivores some are omnivores. Eulipotyphla and Macroscelidea (elephant shrews) species are both insectivores (STANHOPE 1998; GRAHAM et al. 2008).

All ten species (Table 6) have the conservation status "least concern" (LC) according to the International Union for Conservation of Nature (IUCN 2008). The population trend of all caught species is listed as "stable", with the exception of Macroscelides proboscideus (roundeared elephant shrew), whose population trend is "unknown" (IUCN 2008).

On loam a total of 10 species were trapped and on quartz I trapped a total of 4 species. Most individuals were trapped on loamy, heavily grazed plots (Table 6), whereas most species were caught on loamy moderately grazed plots (Table 6). The lowest numbers of individuals and species were caught on heavily grazed quartz plots (Table 6).

Table 6 Overview of trapped species and numbers of individuals (without recaptures) on different habitats under different grazing intensities. $M=$ Macroscelidea, $R=$ Rodentia, E= Eulipotyphla. Points indicate no captures.

\begin{tabular}{|c|c|c|c|c|c|c|c|c|}
\hline \multirow{3}{*}{ Species } & \multirow{3}{*}{ English name } & \multirow{3}{*}{ Family } & \multirow{3}{*}{ Order } & \multirow{3}{*}{$\begin{array}{c}\text { Total } \\
\text { number } \\
\text { of } \\
\text { individuals } \\
\end{array}$} & \multicolumn{4}{|c|}{ Habitat/ Grazing intensity } \\
\hline & & & & & \multicolumn{2}{|c|}{ Loam $(n=12)$} & \multicolumn{2}{|c|}{ Quartz $(n=10)$} \\
\hline & & & & & $\begin{array}{c}\text { Moderate } \\
(n=6)\end{array}$ & $\begin{array}{c}\text { Intensive } \\
(n=6)\end{array}$ & $\begin{array}{c}\text { Moderate } \\
(n=5)\end{array}$ & $\begin{array}{c}\text { Intensive } \\
(n=5)\end{array}$ \\
\hline $\begin{array}{l}\text { Macroscelides proboscideus } \\
\text { (Shaw 1800) }\end{array}$ & $\begin{array}{l}\text { round-eared } \\
\text { elephant shrew }\end{array}$ & Macroscelididae & M & 40 & 9 & 20 & 2 & 9 \\
\hline $\begin{array}{l}\text { Rhabdomys pumilio } \\
\text { (Sparman 1784) }\end{array}$ & $\begin{array}{l}\text { four-striped } \\
\text { grass mouse }\end{array}$ & Muridae & $\mathrm{R}$ & 42 & 5 & 35 & 2 & - \\
\hline $\begin{array}{l}\text { Gerbillurus paeba } \\
\text { (A. Smith 1836) }\end{array}$ & $\begin{array}{l}\text { hairy-footed } \\
\text { gerbil }\end{array}$ & Muridae & $\mathrm{R}$ & 32 & 9 & 17 & 6 & - \\
\hline $\begin{array}{l}\text { Desmodillus auricularis } \\
\text { (A. Smith 1834) }\end{array}$ & $\begin{array}{l}\text { cape short- } \\
\text { eared gerbil }\end{array}$ & Muridae & $\mathrm{R}$ & 9 & 7 & 2 & . & . \\
\hline $\begin{array}{l}\text { Mus minutoides } \\
\text { (A. Smith 1834) }\end{array}$ & pygmy mouse & Muridae & $\mathrm{R}$ & 6 & 5 & 1 & . & . \\
\hline $\begin{array}{l}\text { Aethomys namaquensis } \\
\text { (A. Smith 1834) }\end{array}$ & $\begin{array}{c}\text { namaqua } \\
\text { rock-rat }\end{array}$ & Muridae & $\mathrm{R}$ & 3 & 2 & - & $\cdot$ & 1 \\
\hline $\begin{array}{l}\text { Myomyscus verreauxii } \\
\text { (A. Smith } 1834 \text { ) }\end{array}$ & $\begin{array}{l}\text { verreaux's } \\
\text { mouse }\end{array}$ & Muridae & $\mathrm{R}$ & 3 & 3 & - & • & . \\
\hline $\begin{array}{l}\text { Otomys unisulcatus } \\
\text { (F. Cuvier 1829) }\end{array}$ & karoo bush rat & Muridae & $\mathrm{R}$ & 2 & . & 2 & - & . \\
\hline $\begin{array}{l}\text { Malacothrix typica } \\
\text { (A. Smith 1834) }\end{array}$ & gerbil mouse & Nesomyidae & $\mathrm{R}$ & 1 & 1 & $\cdot$ & $\cdot$ & $\cdot$ \\
\hline $\begin{array}{l}\text { Crocidura cyanea } \\
\text { (Duvernoy 1838) }\end{array}$ & $\begin{array}{l}\text { reddish-grey } \\
\text { musk shrew }\end{array}$ & Soricidae & $\mathrm{E}$ & 1 & 1 & - & - & $\cdot$ \\
\hline Undetermined & - & - & - & 1 & 1 & - & - & - \\
\hline Total number of individuals: & & & & 140 & 43 & 77 & 10 & 10 \\
\hline Total number of species: & & & & $\geq 10$ & 9 & 6 & 3 & 2 \\
\hline
\end{tabular}




\subsection{Diversity and activity of small mammals}

\section{Weather, moon, day of year}

Day of year, air temperature, relative humidity of the air, leaf wetness, rain, waning and waxing moon, and the size of the moon did not significantly influence the number of individuals or number of species, Shannon index or evenness of small mammals (tested with separate GLMs for each variable; $n=22, p>0.05)$. Consequently, these parameters were not taken into account in the following analyses in 3.3.

\section{$\underline{\text { Habitat type }}$}

The numbers of individuals and species, the Shannon index and the evenness of small mammals were higher on loam than on quartz; however, insignificantly for the Shannon index (Table 7). Accordingly, the subsequent analyses of this section (3.3) were carried out separately for quartz and loam.

Table 7 Summary of the GLM results for the dependence of number of individuals and species on habitat type (mean \pm standard deviation), $p$-values printed in bold indicate significant results. Number of replicates $(n)$ varies between the parameters because Shannon index is only defined for species richness $\leq 1$ and evenness for species richness $\leq 2$.

\begin{tabular}{lccccc}
\hline & $\boldsymbol{n}$ & Loam & $\boldsymbol{n}$ & Quartz & $\boldsymbol{p}$-value \\
\hline Number of individuals & 12 & $10.0 \pm 13.4$ & 10 & $2.0 \pm 2.8$ & $\mathbf{0 . 0 5 0}$ \\
Number of species & 12 & $2.5 \pm 2.2$ & 10 & $0.9 \pm 0.9$ & $\mathbf{0 . 0 3 3}$ \\
Shannon index & 10 & $0.73 \pm 0.70$ & 6 & $0.21 \pm 0.36$ & 0.108 \\
Evenness & 6 & $0.86 \pm 0.08$ & 2 & $0.67 \pm 0.17$ & $\mathbf{0 . 0 2 7}$ \\
\hline
\end{tabular}

\section{Vegetation cover}

The vegetation cover significantly influenced the number of individuals and the Shannon index, but not the species richness (Table 8). On loam, the vegetation cover of the first height class had a significantly negative effect on the species abundance (Table 8). In contrast, the vegetation cover of the third height class significantly influenced the number of species (Table 8 ). The Shannon index was nearly significantly influenced by the total vegetation cover only. On quartz, the vegetation cover had no significant influence on the number of individuals, number of species or on the Shannon index (Table 8). It was not possible to test the significance of the differences of evenness due to an insufficient volume of available data. 
Table 8 Summary of the GLM results for the dependence of number of individuals, number of species and Shannon index on vegetation cover per height classes in the two habitats, $p$-values printed in bold indicate significant results. Number of replicates $(n)$ varies between the parameters because Shannon index is only defined for species richness $\leq 1$ and evenness for species richness $\leq 2$. $B$-Coefficient denotes the slope of the regression.

\begin{tabular}{lccccccc}
\hline & \multirow{2}{*}{ Height class } & \multicolumn{3}{c}{ Loam $(n=12)$} & \multicolumn{3}{c}{ Quartz $(n=10)$} \\
\cline { 3 - 8 } & & $\boldsymbol{n}$ & $\boldsymbol{B}$ & $\boldsymbol{p}$ & $\boldsymbol{n}$ & $\boldsymbol{B}$ & $\boldsymbol{p}$ \\
\hline \multirow{4}{*}{ Number of individuals } & $<15 \mathrm{~cm}$ & 12 & -0.30 & $\mathbf{0 . 0 1 4}$ & 10 & -0.60 & 0.184 \\
& $15-30 \mathrm{~cm}$ & 12 & 0.20 & 0.475 & 10 & -0.37 & 0.207 \\
& $>30 \mathrm{~cm}$ & 12 & 0.43 & $\mathbf{0 . 0 0 1}$ & 10 & 0.40 & 0.314 \\
& Total cover & 12 & 0.03 & 0.802 & 10 & -0.10 & 0.314 \\
\hline \multirow{4}{*}{ Number of species } & $<15 \mathrm{~cm}$ & 12 & -0.09 & 0.323 & 10 & -0.38 & 0.151 \\
& $15-30 \mathrm{~cm}$ & 12 & 0.27 & 0.094 & 10 & -0.39 & 0.092 \\
& $>30 \mathrm{~cm}$ & 12 & 0.16 & 0.159 & 10 & 0.06 & 0.876 \\
& Total cover & 12 & 0.05 & 0.585 & 10 & -0.14 & 0.163 \\
\hline \multirow{3}{*}{ Shannon index } & $<15 \mathrm{~cm}$ & 10 & 0.04 & 0.762 & 6 & -0.27 & 0.776 \\
& $15-30 \mathrm{~cm}$ & 10 & 0.30 & 0.129 & 6 & n.a. \\
& $>30 \mathrm{~cm}$ & 10 & 0.16 & 0.285 & 6 & 1.01 & 0.214 \\
& Total cover & 10 & 0.16 & 0.056 & 6 & 0.21 & 0.582 \\
\hline
\end{tabular}

\section{$\underline{\text { Grazing intensity }}$}

For both habitat types, the number of individuals was higher on intensively grazed plots than on moderately grazed plots, whereas the reverse was true for the number of species, Shannon index and evenness (Table 9). However, these differences were insignificant across both habitat types (Table 9).

Table 9 Summary of the GLM results for the dependence of numbers of individuals, species abundance and number of species, Shannon-index and evenness on different grazing intensities on different habitats (means \pm standard deviations), $p$-values printed in bold indicate significant results. Number of replicates $(n)$ varies between the parameters because Shannon index is only defined for species richness $\leq 1$ and evenness for species richness $\leq 2$.

\begin{tabular}{|c|c|c|c|c|c|c|c|c|c|c|}
\hline & \multicolumn{5}{|c|}{ Loam } & \multicolumn{5}{|c|}{ Quartz } \\
\hline & $n$ & Moderate & $n$ & Intensive & $p$-value & $n$ & Moderate & $n$ & Intensive & $p$-value \\
\hline Number of individuals & 6 & $7.2 \pm 7.9$ & 6 & $12.8 \pm 17.6$ & 0.451 & 5 & $2.0 \pm 2.3$ & 5 & $2.0 \pm 3.5$ & 1.000 \\
\hline Number of species & 6 & $3.0 \pm 2.8$ & 6 & $2.0 \pm 1.7$ & 0.438 & 5 & $1.2 \pm 1.1$ & 5 & $0.6 \pm 0.9$ & 0.364 \\
\hline Shannon index & 5 & $0.9 \pm 0.8$ & 5 & $0.5 \pm 0.5$ & 0.989 & 4 & $0.2 \pm 0.4$ & 2 & $0.2 \pm 0.3$ & 0.271 \\
\hline Evenness & 3 & $0.9 \pm 0.1$ & 3 & $0.8 \pm 0.1$ & $<0.001$ & 1 & 0.8 & 1 & 0.5 & n.a. \\
\hline
\end{tabular}




\subsection{BMI and body weight of two selected species}

The two most frequently captured species (Table 6) were taken to test the influences of the grazing intensity, vegetation cover and habitat type on the BMI and body weight of small mammals at species level. Accordingly, the round-eared elephant shrew (Macroscelides proboscideus) and the striped mouse (Rhabdomys pumilio) were chosen. Additionally, they represent two different guilds, insectivores and omnivores.

\section{$\underline{\text { Sex and age }}$}

Sex had no significant influence on the body-mass index (BMI) and the weight of Macroscelides proboscideus (ANOVA; $n=40, p=0.948$ and $p=0.429$ ). In addition, sex had no significant influence on the BMI of Rhabdomys pumilio (ANOVA; $n=42, p=0.108$ ). In contrast, sex had a significant influence on the weight of Rhabdomys pumilio (ANOVA; $n=42, p=0.002$ ). To treat both species in the same way in terms of statistical analyses, the data for male and female individuals of both species were pooled. Age had a significant influence on BMI and weight of Rhabdomys pumilio (ANOVA; $n=42, p<0.001$ and $p<0.001$ ), only adult individuals over 32g (APPS et al. 2000) were included in the calculation of BMI (BMI and weight). Of Macroscelides proboscideus only adult individuals (> $32 \mathrm{~g}$ ) were caught.

\section{$\underline{\text { Habitat type }}$}

There were more individuals (not significant) of Macroscelides proboscideus (GLM; $n=22$, $p=0.344$ ) and Rhabdomys pumilio (GLM; $n=22, p=0.161$ ) on loam than on quartz (also see Table 6). Habitat had no significant influence on the BMI of Macroscelides proboscideus (ANOVA; $n=40, p=0.193$ ), but a significant influence on its weight, which was higher on loam plots (ANOVA; $n=40, p=0.044$ ). Habitat had no significant influence on the BMI (ANOVA; $n=26, p=0.750$ ) or weight of Rhabdomys pumilio (ANOVA; $n=26, p=0.694$ ). The subsequent analyses of 3.4 were carried out separately for quartz and loam.

\section{$\underline{\text { Vegetation cover }}$}

The vegetation cover of none of the different height classes had a significant effect on the BMI of Rhabdomys pumilio (Table 10). The weight of Rhabdomys pumilio was significantly higher at high vegetation cover of height class $15-30 \mathrm{~cm}$ and high total vegetation cover (Table 10). The BMI and weight of Macroscelides proboscideus was positively influenced by the total vegetation cover (significant). 
Table 10 Summary of the linear regression results for the dependence of BMI and weight on vegetation cover per height classes, $p$-values printed in bold indicate significant results. $B$-Coefficient denotes the slope of the regression.

\begin{tabular}{|c|c|c|c|c|c|c|c|}
\hline \multirow{2}{*}{ Species } & \multirow{2}{*}{ height class } & \multicolumn{3}{|c|}{ BMI } & \multicolumn{3}{|c|}{ Weight } \\
\hline & & $\boldsymbol{B}$ & $R^{2}$ & $p$ & $\boldsymbol{B}$ & $R^{2}$ & $p$ \\
\hline \multirow{3}{*}{$\begin{array}{l}\text { Rhabdomys pumilio } \\
(n=26)\end{array}$} & $<15 \mathrm{~cm}$ & 0.45 & 0.05 & 0.165 & 0.15 & 0.01 & 0.633 \\
\hline & $>30 \mathrm{~cm}$ & -0.12 & 0.01 & 0.536 & -0.15 & 0.02 & 0.403 \\
\hline & Total cover & 1.62 & 0.05 & 0.132 & 2.05 & 0.09 & 0.045 \\
\hline \multirow{3}{*}{$\begin{array}{l}\text { Macroscelides proboscideus } \\
(n=40)\end{array}$} & $15-30 \mathrm{~cm}$ & -0.00 & 0.00 & 0.894 & -0.02 & 0.00 & 0.909 \\
\hline & $>30 \mathrm{~cm}$ & 0.00 & 0.04 & 0.228 & 0.17 & 0.09 & 0.057 \\
\hline & Total cover & 0.02 & 0.14 & 0.017 & 0.54 & 0.17 & 0.008 \\
\hline
\end{tabular}

\section{$\underline{\text { Grazing intensity }}$}

On loam, the grazing intensity had no significant influence on the BMI (ANOVA; $n=40$, $p=0.083$ ) and on the weight (ANOVA; $n=40, p=0.357$ ) of Macroscelides proboscideus. On quartz, the grazing intensity had no significant influence on the BMI (ANOVA; $n=40$, $\mathrm{p}=0.159$ ) and on the weight of Macroscelides proboscideus (ANOVA; $n=40, p=0.198$ ) either. The low number of caught individuals of Rhabdomys pumilio on quartz was the main reason that for this species the influence of grazing on quartz could not be analysed. On loam, the grazing intensity had no influence on the BMI (ANOVA; $n=22, p=0.555$ ) or on the weight of Rhabdomys pumilio (ANOVA; $n=22, p=0.511$ ). 


\subsection{Seed predation and dispersal}

\section{Weather, moon, day of year}

The moon size influenced the number of removed seeds significantly negatively in the permeable exclosure type and on the control (Table 11). The day of year only influenced the predation in the impermeable exclosure type significantly positively. The leaf wetness influenced the number of removed seeds significantly positively in the permeable exclosure type. As the influence of the weather, moon and day of year on seed predation was very low and the results were not significant for all exclosure types, these data were not considered in the subsequent analyses in 3.5 .

Table 11 Summary of GLM results for the dependence of removed seeds in different exclosure types on different weather data, $p$-values printed in bold indicate significant results, $n=60$. B-Coefficient denotes the slope of the regression.

\begin{tabular}{lccccccccc}
\hline \multirow{2}{*}{ Weather data } & \multicolumn{2}{c}{ Permeable } & & \multicolumn{2}{c}{ Impermeable } & & \multicolumn{2}{c}{ Control } \\
\cline { 2 - 3 } Air temperature & $\boldsymbol{B}$ & $\boldsymbol{p}$ & & $\boldsymbol{B}$ & $\boldsymbol{p}$ & & $\boldsymbol{B}$ & $\boldsymbol{p}$ \\
Relative humidity (air) & 0.00 & 0.953 & & 0.00 & 0.926 & & -0.02 & 0.612 \\
Leaf wetness & -0.02 & 0.365 & & 0.01 & 0.274 & & 0.01 & 0.360 \\
Rain & -0.90 & 0.845 & & -1.71 & 0.720 & & -2.14 & 0.627 \\
Day of year & 0.00 & 0.831 & & 0.03 & $\mathbf{0 . 0 2 1}$ & & 0.00 & 0.834 \\
Moon waning/ waxing & -0.08 & 0.577 & & -0.21 & 0.157 & & -0.13 & 0.361 \\
Moon size & 0.10 & $\mathbf{0 . 0 2 9}$ & & 0.05 & 0.229 & & 0.07 & 0.099 \\
\hline
\end{tabular}

\section{$\underline{\text { Habitat type }}$}

In all exclosure types, significantly more seeds were missing on loam plots than on quartz plots (Table 12). Accordingly, the subsequent analyses in 3.5 were carried out separately for quartz and loam.

Table 12 Summary of GLM results for the dependence of the number of removed seeds on different habitat types in different exclosure types, $n=16$.

\begin{tabular}{lccc}
\hline Exclosure type & Loam & Quartz & $\boldsymbol{p}$-value \\
\hline Impermeable & $12.9 \pm 8.2$ & $5.4 \pm 4.7$ & $\mathbf{0 . 0 0 1}$ \\
Permeable & $25.8 \pm 13.9$ & $7.6 \pm 5.4$ & $<\mathbf{0 . 0 0 1}$ \\
Control & $27.7 \pm 12,7$ & $8.8 \pm 5.9$ & $<\mathbf{0 . 0 0 1}$ \\
\hline
\end{tabular}




\section{$\underline{\text { Vegetation cover }}$}

The total vegetation cover had no significant influence on the number of removed seeds in any exclosure type on both habitat types (Table 13).

Table 13 Summary of linear regression of mean numbers of missing seeds on vegetation cover in different height classes in different exclosure types and on habitat type; $p$-values printed in bold indicate significant results. $B$-Coefficient is the raw regression coefficient; $n=8$.

\begin{tabular}{lccccccc}
\hline \multirow{2}{*}{ Exclosure type } & Height class & \multicolumn{3}{c}{ Loam } & \multicolumn{3}{c}{ Quartz } \\
\cline { 3 - 8 } & & $\boldsymbol{B}$ & $\boldsymbol{R}^{\mathbf{2}}$ & $\boldsymbol{p}$ & $\boldsymbol{B}$ & $\boldsymbol{R}^{\mathbf{2}}$ & $\boldsymbol{p}$ \\
\hline \multirow{4}{*}{ Impermeable } & $<15 \mathrm{~cm}$ & 0.36 & 0.05 & 0.783 & -0.63 & 0.18 & 0.576 \\
& $15-30 \mathrm{~cm}$ & 1.07 & 0.61 & 0.218 & -0.67 & 0.13 & 0.643 \\
& $>30 \mathrm{~cm}$ & 1.11 & 0.47 & 0.312 & -1.48 & 0.16 & 0.601 \\
& Total cover & 0.57 & 0.64 & 0.197 & -0.83 & 0.23 & 0.301 \\
\hline \multirow{3}{*}{ Permeable } & $<15 \mathrm{~cm}$ & 0.70 & 0.09 & 0.696 & -1.19 & 0.32 & 0.431 \\
& $15-30 \mathrm{~cm}$ & $<0.01$ & $<0.01$ & 0.998 & -1.13 & 0.18 & 0.571 \\
& $>30 \mathrm{~cm}$ & 2.00 & 0.81 & 0.099 & -3.50 & 0.44 & 0.339 \\
& Total cover & 0.52 & 0.28 & 0.472 & -1.60 & 0.89 & 0.053 \\
\hline \multirow{4}{*}{ Control } & $<15 \mathrm{~cm}$ & 0.20 & 0.01 & 0.890 & -0.74 & 0.11 & 0.663 \\
& $15-30 \mathrm{~cm}$ & -0.11 & $<0.01$ & 0.928 & -1.08 & 0.15 & 0.612 \\
& $>30 \mathrm{~cm}$ & 1.46 & 0.63 & 0.207 & -2.09 & 0.14 & 0.622 \\
& Total cover & 0.29 & 0.128 & 0.641 & -1.14 & 0.41 & 0.358 \\
\hline
\end{tabular}

\section{$\underline{\text { Grazing intensity }}$}

On loam, more seeds had been removed on moderately grazed than on intensively grazed plots (Table 14). However, this was only significant for permeable exclosures and controls. On quartz, by contrast, the opposite effect occurred, and more seeds were removed on intensively grazed than on moderately grazed plots. The differences on quartz plots were not significant for any of the exclosure types (Table 14).

Table 14 Summary of the GLM results showing the influence of grazing intensity on missing seeds (means \pm standard deviations) on loam and quartz, $p$-values printed in bold indicate significant results; $n=40$.

\begin{tabular}{lccccccc}
\hline \multirow{2}{*}{ Exclosure type } & \multicolumn{3}{c}{ Loam } & & \multicolumn{3}{c}{ Quartz } \\
\cline { 2 - 4 } & Moderate & Intensive & $\boldsymbol{p}$-value & & Moderate & Intensive & $\boldsymbol{p}$-value \\
\hline Impermeable & $14.7 \pm 13.6$ & $11.2 \pm 15.2$ & 0.454 & & $4.0 \pm 4.3$ & $6.8 \pm 11.3$ & 0.277 \\
Permeable & $33.3 \pm 12.9$ & $18.3 \pm 13.2$ & $>\mathbf{0 . 0 0 1}$ & & $6.2 \pm 7.9$ & $9.0 \pm 8.1$ & 0.194 \\
Control & $33.6 \pm 11.7$ & $21.7 \pm 12.6$ & $\mathbf{0 . 0 0 3}$ & & $6.9 \pm 8.0$ & $10.7 \pm 10.5$ & 0.277 \\
\hline
\end{tabular}

Seed predation differs significantly between the animal groups (ANOVA; $n=8, p=0.004$ ). Seed predation by arthropods was significantly higher compared to seed predation by birds (Tukey HSD test; $n=8, p=0.045$ ). By contrast, there was no significant difference between seed predation by small mammals and arthropods (Tukey HSD test; $n=8, p=0.841$ ), as well as between small mammals and birds (Tukey HSD test; $n=8, p=0.133$ ).

All animal groups predated more seeds on loam than on quartz (Table 15). Birds (ANOVA; $n=8, p=0.729$ ) and arthropods (ANOVA; $n=8, p=0.096$ ) predated insignificantly more seeds on loam than on quartz. By contrast, small mammals predated significantly more seeds on 
loam than on quartz (ANOVA; $n=8, p=0.035$ ). Birds, small mammals and arthropods predated insignificantly more seeds on intensively grazed plots than on moderately grazed plots (tested with separate ANOVA for each variable; $n=8, p>0.05$ ).

Table 15 Overview of missing seeds (mean of sums \pm standard deviation) for calculated predation of animal groups on different habitat types under different grazing intensities; $n=8$.

\begin{tabular}{|c|c|c|c|c|}
\hline \multirow{2}{*}{ Calculated animal group } & \multicolumn{2}{|c|}{ Loam } & \multicolumn{2}{|c|}{ Quartz } \\
\hline & Moderate & Intensive & Moderate & Intensive \\
\hline $\begin{array}{l}\text { Bird predation } \\
\text { (=Control minus Permeable) }\end{array}$ & $0.23 \pm 2.53$ & $3.43 \pm 1.22$ & $0.67 \pm 3.78$ & $1.70 \pm 2.29$ \\
\hline $\begin{array}{l}\text { Small mammal predation } \\
\text { (=Permeable minus Impermeable) }\end{array}$ & $18.61 \pm 4.75$ & $7.07 \pm 4.10$ & $2.16 \pm 1.57$ & $2.20 \pm 3.57$ \\
\hline $\begin{array}{l}\text { Arthropod predation } \\
\text { (=Impermeable) }\end{array}$ & $14.71 \pm 3.23$ & $11.22 \pm 11.17$ & $4.01 \pm 3.13$ & $6.80 \pm 3.50$ \\
\hline
\end{tabular}

\section{$\underline{\text { Seed dispersal }}$}

Altogether, $191 \mathrm{~g}$ of dung of indigenous herbivores were collected. From the samples of eight plots (one intensively grazed plot, seven moderately grazed plots) of dung from indigenous herbivores (mainly antelopes), 124 seedlings emerged (Table 16). I found more dung on moderately grazed fields than on intensively grazed fields. Consequently, out of dung from moderately grazed fields more seedlings germinated than out of dung found on intensively grazed fields (Table 16). In total, 12 species of 5 families were identified. For a complete list of taxa and their seedling abundances, see Appendix 9.

Table 16 Number of seedlings, plots and dung mass per grazing intensity

\begin{tabular}{lccccc}
\hline Grazing intensity & $\begin{array}{c}\text { Number of } \\
\text { seedlings }\end{array}$ & $\begin{array}{c}\text { Number of plots } \\
\text { with dung }\end{array}$ & $\begin{array}{c}\text { Dung mass } \\
{[\mathbf{g}]}\end{array}$ & $\begin{array}{c}\text { Seedlings per } \\
\text { plot }\end{array}$ & $\begin{array}{c}\text { Seedlings per } \\
\text { 1g dung mass }\end{array}$ \\
\hline Intensive & 2 & 1 & 12 & 2 & 0.2 \\
Moderate & 122 & 7 & 179 & 17.5 & 0.7 \\
Total: & 124 & 8 & 191 & 15.5 & 0.6 \\
\hline
\end{tabular}




\section{Discussion}

\subsection{Effects of habitat type and different grazing intensities on vegetation cover}

\section{Habitat type}

The vegetation cover was generally very low, but on loamy soils significantly higher than on quartz fields, showing that the habitat type has a significant influence on the vegetation cover. Furthermore, the vegetation cover decreased with increasing vegetation height; the majority of plants have a height below $30 \mathrm{~cm}$. The sparse vegetation cover and the low vegetation height are due to a low precipitation and high average temperatures in the semi-arid study area (MucinA et al. 2006). The fact that the vegetation cover is clearly less dense on quartz fields compared to loam fields is related to particularly unfavourable soil conditions for plants on quartz fields. Compared to loamy soils, quartz fields show an increased edaphic aridity due to the higher stone content in the soil, shallow soil and consequently lower water storage capacity as well as higher salinity in the soil (SCHMIEDEL \& JÜRGENS 1999). Furthermore, quartz fields have partly an extremely acid soil $\mathrm{pH}$ and a lower concentration of carbonate than loamy soils (SCHMIEDEL \& JÜRGENS 1999; HAARMEYER 2009), which impacts the availability of essential or toxic ions (GUREVITCH et al. 2006). These exceptional soil conditions require the plants to adapt in a certain way. Consequently, the unique growth habit of the quartz field vegetation, which is dominated by leaf succulent dwarf shrubs with low height and low cover values (SCHMIEDEL \& JÜRGENS 2004), can be interpreted as an adaptation to the extreme growing conditions of this habitat type.

\section{Grazing intensity}

I did not find a measurable influence of grazing intensity on the vegetation cover in either of the habitat types. This suggests that in the Knersvlakte, habitat conditions influence the vegetation cover more than grazing intensity. My results were unexpected, as other studies for the Succulent Karoo showed that selective grazing and high stocking rates of domestic animals impact the vegetation in terms of coverage, reproduction, mortality of plants and indirectly species composition and abundance of plant communities by altering the competitive relationships between plants (ECCARD et al. 2000; HENDRICKS et al. 2003; TODD $\&$ HOFFMAN 1999). In addition, excessive grazing has often been referred to as an important cause for degradation and biodiversity losses in arid and semi-arid rangelands (CowLING \& Hilton-TAYlOR 1994; Hilton-TAYlOR 1994). The degradation of ecosystems leads to 
habitat changes and even the loss of small mammals' habitats (JOUBERT \& RYAN 1999). The fact that other researchers have come to contrasting results with regard to the vegetation cover could be on the one hand due to a clearly lower grazing intensity on the farms were my research was carried out. On the other hand, shortcomings in my approach of merely estimating the vegetation cover might not have been specific enough and did not consider differences in vegetation. HAARMEYER (2009), who investigated the plant species composition under different grazing intensities in the same year and in the same study area concluded that many years of intensive grazing could lead to changes in the species composition of the vegetation but less so on in vegetation cover.

\subsection{Effects of weather, moon and day of year on small mammals and seed predation}

Weather (temperature, relative humidity of the air, leaf wetness, and rain) had no significant influence on the number of individuals, species richness, Shannon index, or evenness of the trapped small mammals. The analysed weather data showed no extreme outliers or significant variations, which could have seriously influenced the mammals. This is probably due to the fact that the weather in the study area is generally relatively mild and constant (CowLING et al. 1997; MucINA et al. 2006). The seed predation by arthropods was significantly negatively influenced by leaf wetness, i.e. the degree of humidity on the leaf surface. As there was no correlation between rain or fog (i.e. high level of air humidity) and seed predation, the impact of leaf wetness on seed predation by arthropods is considered to be mainly due to the frequent dew formation in the study area. Other than rain and fog, dew only forms after very cold, clear nights. Possibly, low minimum temperatures in combination with a clear sky during nighttimes lead to a lower degree of arthropod activity, as they are less inclined to look for food.

ANDREWS \& O'BRIEN (1999) investigated the dispersal of small mammals according to climate regions southern Africa, found an indirect influence of the weather on the vegetation, and consequently on small mammals needing the vegetation as food and shelter. ANDREWS \& O'BRIEN (1999) assume that a low correlation of small mammal diversity with diurnal temperatures may be a result of their protection from temperature extremes by thick ground vegetation or by their ability to burrow underground.

The moon (waning and waxing moon and size of moon) had no significant influence on the number of trapped individuals, species richness, Shannon index or evenness of small mammals. Merely the seed predation by small mammals was positively influenced by the size 
of the moon. A positive effect of the size of the moon can only be explained by looking at the increased activity of the crepuscular species during dawn and dusk and also in brighter moonlight. These species include rats, for instance, and also insectivores such as elephant shrews. I assume that the moon size respectively the brightness of the moon did not have the excepted negative impact on small mammals or other animals as described by STOKES et al. (2001) because according to my personal observations the night sky was usually very cloudy, which limited the effect of the changing moon phases during the month. As small mammals are more exposed to predators during a night with brighter moonlight, it could have been expected that the moon size would have a strong influence on the activity of small mammals and other animal groups.

The influence of the day of year was low, probably because the time factor was excluded a priori by the experimental design, in which all trapping sessions in different habitat types and grazing regimes took place alternately in time. However, the day of year had a significantly positive influence on seed predation by arthropods. This probably meant that the arthropods are highly influenced in their activity by the season. Perhaps their populations grew towards the end of the study period because of rising temperatures, so that the seed predation increased due to higher food requirements towards to the end of the study period. After SEYMOUR \& DEAN (1999) invertebrates, population levels and assemblages fluctuate considerably over time due to factors such as breeding season and hibernation.

In summary, it could be stated that weather, moon, and day of year only had a significant influence on the activity (e.g. foraging, seed predation) of arthropods. Small mammals were not strongly affected in their activity by these environmental factors.

\subsection{Effects of habitat type and different grazing intensities on small mammals and seed predation}

\section{$\underline{\text { Trapping success }}$}

The mean capture rate including both habitat types was $1.77 \%$. Compared with a study by HOFFMANN \& ZELLER (2005), who recorded a mean monthly trapping success of $3.75 \%$ on intensively grazed plots in the Nama Karoo (arid dwarf shrub savanna) and $7.05 \%$ on plots with low grazing and a study by DECHER \& BAHIAN (1999) in the Accra Plains of Ghana (savanna) who had a mean trapping success rate of $2.23 \%$, my trapping success was very low. The trapping success in this study may have been limited because of the exclusive use of allenclosed Sherman live traps. Perhaps larger, open wire traps, more traps, other distances or 
longer trapping sessions would have been more advantageous, as the capture rate can also depend on the character and size of the traps (SLADE et al. 1993; O'FARREL et al. 1994), as well as on distances, number of traps and number of trapping nights (HAVERON 2008). However, the fact that my capture rate was this low does not necessarily indicate a generally smaller abundance of small mammals in the study area. Small mammal populations occur very patchy and the trap plots were randomly distributed in the investigated area. I suppose the trap plots were not always in coincidence with an area were small mammal populations were presented. Although the number of trapped individuals was small, the proportions of the abundances on the different fields were comparable.

I have observed a positive, insignificant influence of the time of year on the capture rate (cf. 4.2.). This also explains the high standard deviation of the trapping success $(2.96 \% \mathrm{SD}$, $1.77 \%$ Mean). I have started trapping before the beginning of the breeding season (August). At this time, the number of trapped small mammals was very low. In the middle of the breeding season (November), when I stopped trapping, the number of trapped individuals was very high, which can be explained by offspring of the growing populations. NEAL (1986), who mainly worked with rodents, also found out that the abundance varies strongly in the course of the breeding season. As confirmed by NEL (1978), small rodents, which made up the majority of the individuals and species I trapped, as well as the elephant shrews, show a patchy distribution and vary widely over time in their abundance. Therefore, trappings can be highly coincidental.

\section{$\underline{\text { Habitat type }}$}

I trapped significantly more individuals and species on loam than on quartz fields and also the evenness was significantly higher on loam. The Shannon index showed a clear trend to higher values on loamy soils than on quartz fields. Due to the higher trapping success and a higher number of trapped species on loam fields, I conclude that there is a higher abundance and activity of small mammals on loam than on quartz fields. Not only has the higher trapping success allowed me to draw conclusions with regard to the abundance und activity of the small mammals, but also to the seed predation. In both exclosure types, the seed predation was significantly higher on loam than on quartz fields; this includes the seed predation by all animal groups (arthropods, small mammals, birds) which have been concluded from the enclosure types (for details see 2.8). Among the seed predation calculated for the various animal groups, the value for the arthropods is the highest and the seed predation by small 
mammals even higher than by birds. This shows that arthropods are the animal group contributing the most to seed predation. As particularly arthropods do not immediately consume the seeds, but usually carry them into their burrow, they contribute significantly to seed dispersal (ESLER et al. 2006).

All animal groups predated more seeds on loam fields than on quartz fields. This could be due to the fact that living conditions on quartz fields are not only less favourable for plants (c.f. 4.1), but also for animals. The soil surface on quartz fields is highly uneven due to the gravellike quartz stones and small mammals, but also arthropods and birds, find it more difficult to move about on quartz fields than on loam fields, and even birds in the Knersvlakte also move on the ground a lot. This is a disadvantage for the animals, as the search for food thus consumes more energy and it is more difficult to escape from predators. Moreover, small mammals find it more difficult to burrow in quartz fields and thus fewer burrows are created, which leads to a lack of protection from both predators and high temperatures. Particularly in order to avoid extremes of external temperatures, it is necessary for small mammals to be able to hide in underground nestings (PRAKASH 1981). According to WADA et al. (1995), the burrowing limitation restricts the abundance of small mammals.

In order to be able to deal with these environmental conditions, small mammals might have to adapt in a certain way. Probably there are more species on loam fields than on quartz fields, as fewer species have adapted to the more difficult living conditions on the quartz fields. An additional reason for the lower activity of the wildlife and the diversity of small mammals on quartz fields is probably the less dense vegetation cover on quartz fields (cf. 4.1). It is often noted that a lower vegetation cover offers the wildlife less protection from predation and heat (Morse 1980; PARMENTER \& MACMAHON 1983; CASSINI \& GALANTHE 1992), as well as less food in terms of plant matter or insects, living on and of the plants (SEYMOUR \& DEAN 1999; BLAUM 2004; HOFFMANN \& ZELLER 2005). It is suggested by the resource availability hypothesis that the abundance of small mammals is mainly determined by food availability (SEYMOUR \& DEAN 1999; HofFMANN \& ZELLER 2005; Blaum 2004).

The vegetation cover did not have a significant influence on the seed predation and small mammal diversity in the exclosure types or in the controls of either habitat type. However, there was a strong difference in vegetation cover as well as in the abundance and diversity of the small mammals between the habitat types. Combining both results reveals that the vegetation cover is not exclusively responsible for the variation in activity and diversity 
between the habitat types. Probably other parameters such as the species composition of the vegetation, soil parameters, or burrowing opportunities have a greater influence on the activity and diversity of small mammals and other wildlife.

Apparently, the vegetation cover indirectly influenced the abundance and diversity of small mammals and wildlife via the habitat type, as the vegetation cover differed greatly between the two habitat types. Within one habitat type, the vegetation cover merely had an influence on the number of trapped individuals on loamy soils. In the lower vegetation layer (up to 15 $\mathrm{cm})$, the vegetation cover influenced the number of trapped individuals negatively, while the number of trapped individuals in the higher vegetation layer (above $30 \mathrm{~cm}$ ) was influenced positively by the higher density. Probably a vegetation cover below $15 \mathrm{~cm}$ in height is rather unfavourable for the small mammals. The short plants affect the range of vision, create barriers for running animals, and are unsuitable as protection from the sun or predators due to their low height. The higher vegetation cover of up to $30 \mathrm{~cm}$ is probably advantageous for the abundance of the small mammals, as it protects from the sun and thus from high temperatures and may provide a place to hide from predators. According to HuGHES et al. (1994), the plant cover provides an important refuge for rodents to avoid attacks by predators.

Not only the number of individuals and species, but also the species composition differs significantly in the two habitat types. On quartz fields, only a fraction of the species occurring on loamy soils can be found, but there were no additional species. On loam, the most frequently found species were Macroscelides proboscideus and Rhabdomys pumilio and on quartz fields Macroscelides proboscideus and Gerbillurus paeba.

Exclusively nocturnal species such as Desmodillus auricularis, Mus minutoides, and Myomyscus verreauxii were exclusively found on loamy soils, where the vegetation cover was significantly higher than on quartz fields. This is a rather unexpected result, as nocturnal species are not so dependent on the vegetation cover, since nocturnal predators, such as jackals, rely chiefly on hearing and olfactory senses to locate prey (PERRIN et al. 1999). Diurnal species on the other hand appear to favour and be dependent on vegetation cover as diurnal activity exposes them to increased predation (JOUBERT \& RYAN 1999).

Macroscelides proboscideus, an insectivore species, has to be pointed out in particular, as it is the only species occurring on both habitat types and with both grazing intensities. Macroscelides proboscideus was the most frequent species, probably because it is the only species among the trapped small mammals that is known to be able to preserve the high extremes of external temperatures and a limitation in food in torpor (LOVEGROVE 1999). 
Consequently, this species is not dependent on the possibility to grub burrows or to have food all the time, both of which is particularly difficult on quartz fields. Therefore, this species is probably best adapted to deal with the difficult living conditions on quartz fields.

It is noteworthy that all of the species that were most frequently trapped display a social behaviour. Probably social species dispose of the best survival strategies in these extreme environmental conditions. Mutual help strategies ensure the survival, especially in times of draught and aridity, better than individualised solitaire strategies. Schradin \& Pillay (2005), who worked with Rhabdomys pumilio, suggest that group living in the Succulent Karoo is in response to habitat saturation and the benefits of philopatry.

As Macroscelides proboscideus and Rhabdomys pumilio were the most frequent species occurring on the plots, I have examined these two species with regard to their physiological constitution on the different habitat types and under different grazing intensities. According to JАКОВ et al. (1996), the physiological constitution of an animal indicates its nutritional condition and general fitness. The results of my analysis show that the habitat had no significant influence on the BMI of Macroscelides proboscideus and Rhabdomys pumilio, but on the weight of Macroscelides proboscideus. As the habitats are very small and patchy, the animals probably move beyond habitat boundaries and are not limited to one habitat type. As the BMI is similar for both habitat types, I conclude that small mammals are of a comparable physiological constitution in both habitat types. Therefore, the small mammals are not physically disadvantaged by the unfavourable living conditions on quartz fields, as they can go to the loam fields to find food. Possibly, quartz fields are only passed through on their way to look for food.

The fact that significantly lighter individuals (but with a similar BMI) of Macroscelides proboscideus were found on the quartz fields could indicate that these are younger individuals or a smaller quartz ecotype of this species. The latter would contradict the assumption based on the identical BMIs that the small mammals have larger home ranges than the size of an average quartz field. Hence, they are probably younger individuals. The particularly frequent occurrence of young individuals on quartz fields, however, cannot be explained.

The total vegetation cover influenced the BMI and the weight of Macroscelides proboscideus as well as the weight of Rhabdomys pumilio significantly positively. Moreover, a positive but insignificant relationship was found between the BMI of Rhabdomys pumilio and the total vegetation cover. Probably the vegetation cover is so important for the protection and food 
availability in particular for these species that it has an influence on their physiological constitution, as the vegetation cover does not influence the total of all species. Rhabdomys pumilio is the only diurnal species and therefore dependent on the visual protection from predators, as diurnal predators use visual clues for their orientation. This does not explain the impact on Macroscelides proboscideus, as it is both diurnal and nocturnal. Probably this species needs the vegetation cover, as its diet depends on its insects.

Consequently insectivore and omnivore species differ between the two habitat types in terms of their distribution, but are not influenced in clearly different ways by habitat types and vegetation cover with regard to their physiological constitution.

\section{$\underline{\text { Grazing intensity }}$}

The numbers of trapped individuals as well as the diversity of the small mammals were not significantly influenced by the grazing intensity. Merely negative trends were found. This is an unexpected result, as other studies in the arid regions of southern Africa (HOFFMANN \& ZELLER 2005; JOUBERT\& RYAN 1999) demonstrate that intensive grazing leads to lower trapping success, number of individuals, species richness, and Shannon index compared to a low grazing intensity or no grazing. As already discussed in section 4.1, the lack of impact on small mammals also suggests that the grazing pressure in the intensively grazed plots was not as strong as in other studies. However, my results for both habitat types show a trend to higher species richness on moderately grazed fields and a higher abundance on intensively grazed fields. JOUBERT \& RYAN (1999) also showed a higher species richness in sites with a lower grazing intensity or ungrazed sites, with HESKE \& CAMPBELL (1991) additionally showing abundance increases.

Species sensitive to habitat disturbance are probably more likely to occur on moderately grazed fields than on intensively grazed fields, as they are less disturbed by domestic livestock and sheep dogs. According to Bowland \& PERrin (1988), und HofFManN \& ZELLER (2005) small mammals can be negatively affected by heavy grazing pressure from ungulates. The fact that there are more individuals found on intensively grazed fields on loamy soil could be due to a lower number of species that are more resistant to stress. Probably there is less interspecific competition for food and space, which increased the abundances of the few dominating species in these fields. On the other hand, the altered composition of the vegetation due to intensive grazing reduces the food available for the small mammals, which makes them more active, as they have to roam further for food and consequently the bait in the traps were more attractive. I did not recognise a trend influenced 
by grazing intensity regarding a certain food preference, diurnality, or nocturnality in the species composition.

On loamy soils the seed predation in the permeable exclosure types (mainly small mammals) and in the controls (mainly birds) was negatively influenced (significant) by the grazing intensity, while the seed predation in the impermeable exclosure types (mainly arthropods) was not significantly influenced, but showed a negative trend. Probably activities such as foraging are more intensive on moderately grazed loam fields than on intensively grazed fields, as small mammals, arthropods and birds are less disturbed by domestic livestock.

However, on quartz fields the grazing intensity had no influence on seed predation in any of the exclosure types or the control plot. Probably seed predation is generally lower on quartz due to the unfavourable living conditions and the consequently lower wildlife abundance (see section 4.3). Moreover, the grazing intensity had not significant influence on the BMI or the weight of Macroscelides proboscideus and Rhabdomys pumilio. Therefore the physiological condition was not influenced by different habitat types or grazing intensities. This is probably due to the fact that the most frequently occurring species are also the most stress resistant, which are less sensitive to disturbances by domestic livestock. This indicates that none of the two species hold a dietary advantage with regard to their physical condition in intensively grazed fields or in different habitat types. The fact that the grazing intensity had no significant impact on the calculated seed predation of the different animal groups or on the physical constitution of the small mammals also suggests that even the intensive grazing pressure was fairly low compared to other studies (see section 4.1).

\subsection{Effects of indigenous herbivores on vegetation}

The germinated plant individuals represented a small spectrum of species and families. The species frequency is unevenly distributed across the families. I assume that on intensively grazed fields indigenous herbivores are less frequent, because on the intensively grazed fields less dung of indigenous herbivores was found as compared to the moderately grazed fields. Germination experiments revealed that the collected dung of indigenous herbivores contained only a low number of viable Aizoaceae and Asteraceae seeds, although species of Aizoaceae and Asteraceae were quite abundant in the established vegetation (personal observation). Consequently, I conclude that indigenous herbivores play a minor role for seed dispersion of these families. Aizoaceae usually shows short-distance ombrohydrochorous dispersal, a specific adaptation to abiotic environmental conditions like fine-scale habitat variation (ELLIS \& WEIS 2006) and intra-annual rainfall patterns (PAROLIN 2006). Data also showed that no 
endemic plant species germinated from the dung collected. This is probably because endemic species make up only a small amount of the biomass. Additionally, vegetation is selectively grazed by indigenous herbivores. Previous studies revealed that duiker are selective feeders and predominantly browsers (KIGOZI 2003), steenbok are purely browsers by preference, and not mixed feeders as has previously been assumed (DU TOIT 2008). Antelopes generally prefer fleshy-fruited species (e.g. Fabaceae, Asteraceae) (Milton \& DEAN 2001). Thus, species richness of viable seeds in the dung is expected to be low and do not reflect the composition of the standing vegetation. It should be noted that the in general low species spectrum found within the dung samples might be due to the small amount of samples taken, and more species would have been found if the sampling effort had increased. Germination of endozoochoric dispersed seeds is determined by a variety of parameters. The seed has to survive the digestive system (COSYNS et al. 2005) and dormancy breaking and germination requirements have to be fulfilled (MALO 2000).

According to MiLtON \& DEAN (2001) only 6-8\% of Succulent Karoo plant species have seeds dispersed by endozoochory. Thus, looking at the discrepancy of the rich vegetation at the study sites and the low species numbers found by means of the germination experiments, the results support the findings of MiLTON \& DEAN (2001).

Under the assumption of the same sampling effort, the sparse occurrence of wildlife dung on the intensively grazed fields might indicate a low density of indigenous herbivores.

\subsection{Conclusion and implication for nature conservation}

In this thesis, the interactions between wildlife and vegetation cover under different livestock grazing intensities and habitat types in the semi-arid Knersvlakte, South Africa were investigated. The research was carried out in order to provide basic insights assisting the management of the Knersvlakte Conservation Area with future management decisions.

The results of this study revealed that the interactions between domestic livestock, vegetation cover and wildlife, especially small mammals in the Succulent Karoo are complex. Moreover, due to a small number of replicates, the results were only partly significant. During my study, I found differences in number of individuals, species richness, species composition and the activity of small mammals with regard to seed predation across central Knersvlakte.

The local conditions of the habitats had a stronger effect on the vegetation cover, small mammal abundance and number of species than different grazing intensities. As these results are not in line with other studies in the literature review (HOFFMANN \& ZELLER 2005; 
JOUBERT \& RYAN 1999), I assume that the grazing pressure in the study area was not very high, i.e. not comparable to the plots identified as "intensively grazed" in other studies.

However, grazing had a rather negative effect on species richness and species composition of small mammals, as well as on seed predation by small mammals, arthropods and indigenous herbivores. The species composition of small mammals on intensively grazed fields was only a subset of that on moderately grazed fields. Probably species sensitive to habitat disturbance and easily stressed by domestic livestock exclusively occur on plots with a low grazing intensity. Reduced seed dispersal by small mammals, arthropods and indigenous herbivores under high grazing pressure could have negative long-term consequences for vegetation dynamics. Studies have already been carried out (KELLER \& SCHRADIN 2008) that prove the fact that small mammals can have a positive effect on plant species richness and should therefore be included in conservation programs of the Succulent Karoo in areas of high small mammal richness. In order to better understand the impact of grazing on small mammals and other wildlife and their influence on the fragile vegetation and its slow dynamics in the Knersvlakte and in order to preserve the original and typical biodiversity of this region, additional longer-term studies are needed.

Overall, the results indicate that a high grazing intensity by domestic livestock has a negative influence on species richness and activity with regard to foraging and seed predation by small mammals, arthropods and indigenous herbivores. A high biodiversity is of paramount importance, as it can lead to greater resilience of the ecosystem against changing environmental conditions (e.g. climate change) (THOMAS et al. 2004). As it is impossible to predict the impact of the reduction in species richness of small mammals, and consequently lower activity levels with regard to seed predation, on the vegetation, the results of this study indicate that it would be advisable to reduce domestic livestock grazing in the planned Conservation Area in the long run. 


\section{References}

Absa Group Economic Research (2003). Game Ranch Profitability in Southern Africa. $A B S A$, South Africa.

Anderson, P. M. L. \& Hoffman, M. T. (2007). The impacts of sustained heavy grazing on plant diversity and composition in lowland and upland habitats across the Kamiesberg. Journal of Arid Environments 70, 686-700.

Apps, P., Aвbоtт, C., Meakin, P. (2008). Smither's Mammals of Southern Africa: A Field Guide. Southern Book Publishers, Johannesburg.

Avenant, N. L. (2000). Small mammal community characteristics as indicators of ecological disturbances in the Willem Pretorius Nature Reserve, Free State, South Africa. South African Journal of Wildlife Research 30, 26-33.

AVERY, D. M. (1993). Last interglacial and Holocene altithermal environments in South Africa and Namibia: micromammalian evidence. Paleoclimatology, Palaeoclimatology, Palaeoecology 101, 221-228.

AYYAD, M. A. (2003). Case studies in the conservation of biodiversity: degradation and threats. Journal of Arid Environments 54, 165-182.

BEER, J. (1964) Bait preference of some small mammals. Journal of Mammalogy 45, 632634.

BIOTA South AfRICA (2007) Weather station data of observatory 'Moudverloren'. Contact: Ute Schmiedel, Institute of General Botany, University of Hamburg; Klaus Berger, Institute of Soil Science, University of Hamburg.

Blaum, N., Rossmanith, E. \& Jeltsch, F. (2007). Land use affects rodent communities in Kalahari savannah rangelands. Journal of African Ecology 45, 189-195.

Boonstra, R. \& KReBS J. R. (1976). The effect of odour on trap response in Microtus townsendii. Journal of Zoology 180, 467-476.

Bowland, A. E. \& PERrin, M. R. (1988). The effect of overgrazing on small mammals in Umfolozi Game Reserve. Zeitschrift für Säugetierkunde 54, 251-60.

Cassini, M. H. \& Galanthe, M. L. (1992). Foraging under predation risk in the wild guinea pig the effect of vegetation height on habitat utilisation. Annales Zoologici Fennici 29, 285-290. 
ChoAte, T. S. (1972). Behavioural studies on some Rhodesian rodents. Zoologica Africana 7 , 103-118.

CONSERVATION INTERNATIONAL (2008). Biodiversity Hotspots. Web: http://www.biodiversityhotspots.org; last access: 20.01.2009.

Chris \& STUART (1994). A Field Guide to the Tracks and Signs of Southern and East African Wildlife. Struik Publisher (Pty) Ltd 2000.

Cosyns, E., Delaporte, A., Lens, L., Hoffmann, M. (2005). Germination success of temperate grassland species after passage through ungulate and rabbit guts. Journal of Ecology 93, 353-361.

Cowling, R. M., Esler, K. J., Rundel, P. W. (1999). Namaqualand, South Africa - an overview of a unique winter-rainfall desert ecosystem. Plant Ecology 142, 3-21.

Cowling, R. M., PIERCE, S. M. (1999). Namaqualand. A Succulent desert. Fernwood Press, Cape Nature.

Cowling, R. M., Richardson, D. M., Pierce, S. M. (1997). Vegetation of South Africa. Cambridge, United Kingdom: Cambridge University Press.

Cowling, R. M., \& Hilton-Taylor, C. (1994). Patterns of plant diversity and endemism in southern Africa: an overview. Pp. 31-52. In: HunTLEY, B. J. (ed.). Botanical diversity in southern Africa. National Botanical Institute, Pretoria.

DARKOH, M. B. K (2002). Regional perspectives on agriculture and biodiversity in the drylands of Africa. Journal of Arid Environments 54, 261-279.

Dean, W. R. J. \& Milton, S. J. (1999). Animal foraging and food. In: Dean, W. R. J. \& Milton, S. J (eds.). The Karoo: Ecological patterns and processes. Pp. 164-177. Cambridge, England: Cambridge University Press.

Dean, W. R. J., \& Milton, S. J. (1999). The Karoo. Cambridge, England: Cambridge University Press.

DECHER, J. \& BAHIAN, L. K. (1999). Diversity and structure of terrestrial small mammal communities in different vegetation types on the Accra Plains of Ghana. Journal of Zoology 247, 395-408.

Desmet, P. G., Cowling, R. M. (1999). Biodiversity, habitat and range-size aspects of a flora from a winter-rainfall desert in north-western Namaqualand, South Africa. Plant Ecology 142, 23-33. 
DeSMET, P. G. (2007). Namaqualand - a brief overview of the physical and floristic environment. Journal of Arid Environment 70, 570-587.

DRICKAMER, L. (1995). Odours in traps: Does most recent occupant influence capture rates for house mice? Journal of Chemistry Ecology 21, 541-555.

DU ToIT, J. T. (2008). The feeding ecology of a very small ruminant, the steenbok (Raphicerus campestris). African Journal of Ecology 31, 35-48.

Du Toit, J. T. \& Broomhall, L. S. (2000). Mammal research in southern Africa: present patterns and future priorities. South African Journal of Science 96, 225-230.

Els, L. M. \& Kerley, G. I. H. (1996). Biotic and abiotic correlates of small mammal community structure in the Groendal Wilderness Area, Eastern Cape, South Africa. Koedoe 39, 121-130.

EcCARD, J. A., WALter, R. B., MiLton, S. J. (2000). How livestock grazing affects vegetation structures and small mammal distribution in the semi-arid Karoo. Journal of Arid Environments 46, 103-106.

Ellis, A. G. \& WeIS, A. E. (2006). Coexistence and differentiation of 'flowering stones': the role of local adaptation to soil microenvironment. Journal of Ecology 94, 322-335.

ENVIRONMENTAL AFFAIRS \& TOURISM RSA (2005). South Africa's national biodiversity strategy and action plan. Web: http://www.cbd.int; last access 07.02.2009.

Esler, K. J., Milton, S. J., Dean, W. R. (2006). Karoo Veld - Ecology and Management. Briza Publications, Pretoria.

FARMER, H., \& MiLTON, S. J. (2006). Comparison of broad-scale plant species preferences of indigenous herbivores in a nature reserve in the Little Karoo with those of domestic smallstock. South African Journal of Science 102, 311-316.

FERreIRA, S. M. \& VAN AARDE, R. J. (1999). Habitat associations and competition in Mastomys-Saccostomus-Aethomys assemblages on coastal dune forests. African Journal of Ecology 37, 121-136.

Forest, F., Grenyer, R., Rouget, M., Davies, T. J., Cowling, R. M., Faith, D. P., Balmford, A., Manning, J. C., Proches, S., van der Bank, M., Reeves, G., Hedderson, T. A. J., Savolainen, V. (2007). Preserving the evolutionary potential of floras in biodiversity hotspots. Nature 445, 757-760. 
Gardner, W., Mulvey, E. M., Shaw, E. C. (1995). Regression Analyses of Counts and Rates: Poisson, Overdispersed Poisson, and Negative Binomial Models. Psychological Bulletin 3, 392-404.

GLIWICZ, J. (1985). Rodent community of dry African savanna: population study. Mammalia $49,509-516$.

Gurevitch, J., Scheiner, S. M., Fox, G. A. (2006). The Ecology of Plants. Sinauer Associates, Inc. Sunderland, Massachusetts, USA.

HAARMEYER, D. H. (2009). Effects of domestic livestock on the vegetation of the Knersvlakte, South Africa. Diploma thesis, University of Hamburg.

HaPpold, D. C. D. (2001). Ecology of African Small Mammals. In: DenYs, C., Granjon, L. \& Poulet, A. Boudy. (eds.). African Small Mammals. Collection Colloques et Seminaires, Paris.

HARPER, J. L. (1969). The role of predation in vegetational diversity. Brookhaven Symposium of Biology 22, 48-62.

HAVEron, S. E. (2008). Comparing small mammal assemblages between communal and commercial rangelands within a region of the Succulent Karoo, South Africa. Master thesis. Stellenbosch University.

Heske, E. \& CAMPBell M. (1991) Effects of an 11-year livestock exclosure on rodent and ant numbers in the Chihuahuan Desert, Southeastern Arizona. Southwestern Naturalist $36,89-93$.

Hendricks, H.H., Bond, W.J., Midgley, J.J., \& Novellie P.A. (2005). Plant species richness and composition a long livestock grazing intensity gradients in a Namaqualand (South Africa) protected area. Plant Ecology 176, 19-33.

Hilton-Taylor, C. (1994). Karoo-Namib region: western Cape domain (Succulent Karoo). In: Davis, S. D., Heywood, V. H. (eds.). Centres of plant diversity: a guide and strategy for their conservation. Oxford University Press, Oxford, 204-217.

Hilton-Taylor, C. (1996). Patterns and characteristics of the flora of the Succulent Karoo Biome, southern Africa. In: VAN Der MAEsen, L. J. E., VAN DER Burgt, X. M. \& VAN Medenbach De Rooy, J. M. (eds.). The Biodiversity of African Plants 58-72. Kluwer Academic Publishers BV. Dordrecht, Niederlande. 
Hilton-Taylor, C. \& le Roux, A. (1989). Conservation status of the fynbos and karoo biomes. 202-223. In: HunTLEY, B.J. (ed.). Biotic diversity in southern Africa: concepts and conservation. Oxford University Press, Cape Town.

Hoffman, M. T., Allsopp, N., Rohde, R. F. (2007). Sustainable land use in Namaqualand, South Africa: Key issues in an interdisciplinary debate. Journal of Arid Environments $70,561-569$.

Hoffmann, A. \& ZELLER, U. (2005). Influence of variations in land use intensity on species diversity and abundance of small mammals in the Nama Karoo, Namibia. Belgian Journal of Zoology 135, 91-96.

Hughes, J. J., Ward, D., Perrin, M. R. (1994). Predation risk and competition affect habitat selection and activity of Namib Desert gerbils. Ecology 61, 1397-1405.

IUCN 2008. 2008 IUCN Red List of Threatened Species. Web: http://www.iucnredlist.org; last access: 22.10.2008.

JaKob, E. J., Marshall, S. D. \& Uetz, G. W. (1996). Estimating fitness: a comparison of body condition indices. Oikos 77, 61-67.

JOUBERT, D. and P. RYAN (1999). Differences in mammal and bird assemblages between commercial and communal rangelands in the Succulent Karoo, South Africa. Journal of Arid Environments 43, 287-299.

Keller, C. \& Schradin, C. (2008). Plant small mammal richness correlate positively in a biodiversity hotspot. Biodiversity Conservation 17, 911-923.

Kerley, G. I. H., KNight, M. \& Erasmus, T. (1990). Small mammal microhabitat use and diet in the southern Kalahari. South African Journal of Wildlife Research 20, 123-126.

KERLEY, G. I. H. (1992). Ecological correlates of small mammal community structure in the semi-arid Karoo, South Africa. Journal of Zoology London 227, 12-27.

KigOzI, F.(2003) The significance of chicory to the diet of common duiker at Grants valley, Eastern Cape Province, South Africa. African Journal of Ecology 41, 289-293.

Kleizen, C., Midgley, J. \& Johnson, S. D. (2008). Pollination Systems of Colchicum (Colchicaceae) in Southern Africa: Evidence for Rodent Pollination. Annals of Botany $102,747-755$.

KRUG, C. (2002). Adaptations of the four-striped field mouse (Rhabdomys pumilio, Sparrman 1784) to the Namib Desert. PhD. Thesis, University of Bonn, Germany. 
Le Roux, A. (2005). Namaqualand - South African Wild Flower Guide 1. Botanical Society of South Africa, Cape Town.

LINZEY, A. V. \& KESNER, M.H. (1997). Small mammals of a woodland- savannah ecosystem in Zimbabwe. II. Community structure. Journal of Zoology London 243, 153-162.

Lovegrove, B. G., Lawes, M. J., Roxburgh, L. (1999). Confirmation of pleisiomorphic daily torpor in mammals: the round-eared elephant shrew Macroscelides proboscideus (Macroscelidea). Journal of Comparative Physiology B-Biochemical Systemic and Environmental Physiology 169, 453-460.

lombard, A. T., Hilton-Taylor, C., Rebelo, A. G., Pressey, R. L., Cowling, R. M. (1999). Reserve selection in the Succulent Karoo, South Africa: coping with high compostional turnover. Plant Ecology 142, 35-55.

MacKellar, N. C., Hewitson, B. C., Tadross, M. A. (2007). Namaqualand's climate: Recent historical changes and future scenarios. Journal of Arid Environments 70, 604614.

Mathis, V., Whitford, W., KAyA, F. \& AlKon, P. (2006). Effects of grazing and shrub removal on small mammal populations in southern New Mexico, USA. Journal of Arid Environments 66, 76 - 86.

Milton, S. J. \& DeAn, W. R. J. (2001). Seeds dispersed in dung of insectivores and herbivores in semi-arid southern Africa. Journal of Arid Environments 47, 465-483.

Milton, S. J., Yeaton, R. I., Dean, W. R. J. \& Vlok, J. H. J. (1997). Succulent Karoo, Pp. 131-166. In: Cowling, R. M., Richardson, D. M. \& Pierce, S. M. (eds.). The Vegetation of Southern Africa. Cambridge University Press, Cambridge.

Morse, D. H. (1980) Behavioural Mechanisms in Ecology. Harvard University Press, Cambridge.

Mucina, L., Jürgens, N., Le Roux, A., Rutherford, M., Schmiedel, U., Esler, K., Powrie, L., Desmet, P. \& Milton S. (2006). Succulent Karoo Biome. Pp. 220 - 299 in Mucina, L. \& Rutherford M. (eds.) (2006). The vegetation of South Africa, Lesotho and Swaziland. South African National Biodiversity Institute, Pretoria: Strelitzia 19.

MucinA, L. \& Rutherford M. (eds.) (2006). The vegetation of South Africa, Lesotho and Swaziland. South African National Biodiversity Institute, Pretoria: Strelitzia 19. 
Myers, N., Mittermeier, R., Mittermeier, C., DA Fonseca, G. \& J. Kent (2000). Biodiversity hotspots for conservation priorities, Nature 403, 853-858.

NeAL, B. R. (1986). Reproductive characteristics of African small mammals. Cimbebasia 8, 113-127.

NEL, J. A. J. (1978). Habitat heterogeneity and changes in small mammal community structures and resource utilisation in the southern Kalahari. Bulletin of the Carnegie Museum of Natural History 6, 118-32.

NyAKo-LARTEY, Q. \& BAXTER, R.M. (1995). The effects of different grazing regimes on the population dynamics of small mammals in the Eastern Cape. Transactions of the Royal Society of South Africa 50, 143-151.

O’’Farrel, M. J., Clark, W. A., Emmerson, F. H., Juarez, S. M., Kay, F. R., O’́Farrel, T. M. \& Godlet, T. Y. (1994). Use of a mesh live trap for small mammals: are results from Sherman live traps descriptive? Journal of Mammalogy 75, 692-699.

PARMENTER, R. R. \& J. A. MACMAHON (1983). Factors determining the abundance and distribution of rodents in a shrub-steppe ecosystem: the role of shrubs. Oecologia (Berlin) 59,145-156.

PAROLIN, P. (2006). Ombrohydrochory: rain-operated seed dispersal in plants - with special regard to jet-action dispersal in Aizoaceae. Flora 201, 511- 518.

PATRIC, E. (1970). Bait preference in small mammals. Journal of Mammalogy 51, 179-182.

PRAKASH, I. (1981). Ecology of the Indian desert gerbils. Meriones hurricane. CAZRI monograph No. 10, Central Arid Zone Research Institute, Jodhpur.

Perrin, M., Dempster, E. and C. Downs (1999) Gerbillurus paeba. Mammalian Species. American Society of Mammalogists 606, 1-6.

Price, M. V., Jenkins, S.H. (1986). Rodents as seed consumers and dispersers. In: Seed dispersal (ed. D. R. Murray) pp. 191-235. Academic Press, Sidney.

QuinN, G. P., KeOUgh, M. J. (2002). Experimental Design and data analysis for Biologists. Cambridge University Press, Cambridge.

Rohde, R., Hoffmann, M. T., Allsopp, (2007). Hanging on a wire: A historical and socioeconomic study of Paulshoek village in the communal area of Leliefontein, Namaqualand. Programme for Land and Agrarian Studies Research report no. 17. Hansa Reproprint, Cape Town. 
Rutherford, M. C. \& Westfall, R. H. (1986). Biomes of southern Africa - an objective categorization. National Botanical Institute. Pretoria (South Africa).

SCHLitTER, D. A. (1978). Problems and priorities on research on the taxonomy and ecology of African small mammals. Bull. Carnegie Museum of Natural History 6, 211-214.

SCHMIEDEL, U. \& JÜRgENS, N. (1999). Community structure on unusual habitat islands: quartz-fields in the Succulent Karoo, South Africa. Plant Ecology 142, 57-69.

SchmiEdel, U. (2002). The quartz fields of southern Africa. Flora, phytogeography, vegetation, and habitat ecology. $\mathrm{PhD}$ Dissertation, University of Cologne.

SCHRADIN, C. (2006). Whole-day follows of striped mice (Rhabdomys pumilio), a diurnal murid rodent. Journal Ethology 24, 37-43.

Schradin, C., Pillay N. (2005a). Demography of the striped mouse (Rhabdomys pumilio) in the Succulent Karoo. Mammal Biology 70, 84-92.

Schradin C, PILlay N. (2005b). Intraspecific variation in the spatial and social organization of the African striped mouse. Journal of Mammalogy 86, 99-107.

SEYMOUR, C. L. \& DEAN, W.R.J. (1999) Effects of heavy grazing on invertebrate assemblages in the Succulent Karoo, South Africa. Journal of Arid Environment 43, 267-286.

SimOnS, L. \& ALlsopP, N. (2007). Rehabilitation of Rangelands in Paulshoek, Namaqualand: Understanding vegetation change using biophysical manipulations. Journal of Arid Environments 70, $755-766$.

Slade, N. A., Eifler, M. A., Gruenhagen, N. M. \& Davelos, A., L. (1993). Differential effectiveness of standard and long Sherman livetraps in capturing small mammals. Journal of Mammalogy 74, 156-161.

Stanhope, M. J., Waddell, V.G., Madsen, O., De Jong, W., Hedges, S. B., Cleven, G. C., KAO, D., Springer, M. S. (1998). Molecular evidence for multiple origins of Insectivora and for a new order of endemic African insectivore mammals. Proceedings of the National Academy of Sciences of the United States of America 95, 9967-9972.

STATSoft, Inc. (2007). Electronic Statistics Textbook. StatSoft. STATISTICA für Windows (Software-System für Datenanalyse). Version 8.0. Web: http://www.statsoft.com/, Tulsa, Oklahoma. 
Stokes, M., Slade, N. and S. Blair (2001) Influences of weather and moonlight on activity patterns of small mammals: a biogeographical perspective. Canadian Journal of Zoology 79, $966-972$.

Stuart, C. \& Stuart, T. (2001). Field Guide to Mammals of Southern Africa. R. Curtis Books Publishers, 2000.

Tabeni, S., Mastrantonio, L. \& OjedA, R. (2007). Linking small desert mammal distribution to habitat structure in a protected and grazed landscape of the Monte, Argentina. Acta Oecology 31, 25- 269.

Thomas, C. D., Cameron, A., Green, R. E., Bakkenes, M., Beaumont, L.J., Collingham, Y. C., Barend F., Erasmus, N., De Siqueira, M. F., Grainger, A., Hannah, L., Hughes, L., Huntley, B., Van Jaarsveld, A. S., Midgley, G. F., Miles, L., Ortega-Huerta, M.A., Townsend Peterson, A., Phillips, O. L \& Williams S. E. (2004). Extinction risk from climate change. Nature 427, 145-148.

TodD, S. W. \& Hoffmann, M. T. (1999). A fence line contrast reveals effects of heavy grazing on plant diversity and community composition in Namaqualand, South Africa. Plant Ecology 142, 169-178.

Wada, N., NARita, K., Kumar, S., Furukawa, A. (1995). Impact of overgrazing on seed predation by rodents in the Thar desert, northwestern India. Ecological Research 10, 217-221.

WADA, N., UEMURA, S. (1994). Seed dispersal and predation by small rodents on herbaceous understory plants Symplocarpus renifolius. American Midland Naturalist 123, 320327.

Willan, K., MEester, J. (1989). Life-history styles of southern African Mastomys natalensis, Otomys irroratus and Rhabdomys pumilio (Mammalia, Rodentia). In: BRUTON, M.N. (ed.). Alternative life-history styles of animals 421-439. Kluwer Academic Publishers BV. Dordrecht, Niederlande 


\section{Abbreviations}

am. ante meridiem

ANOVA. analysis of variance

BMI body mass index

c.f. confer

$\mathrm{cm}$. centimetre

e.g. exempli gratia

GIS Geographic Information System

GPS Global Positioning System

h. .hours

ha. hectare

i.e id est

$\mathrm{m}$. metre

$\min$. minute

n.a. not analysed

$\mathrm{pm}$ post meridiem SSU .small stock unit

WGS 84 World Geodetic System 1984 


\section{Appendices}

Appendix 1 GPS-data of the exclosure plots in chronological order. Reference system: WGS 84.

\begin{tabular}{|c|c|c|c|c|c|}
\hline Exclosure Plot & Latitude & Longitude & Farm & Habitat & Grazing intensity \\
\hline 1 & $-31,344384486$ & 18,602516949 & Ratelgat & loamy & moderate \\
\hline 2 & $-31,406698907$ & 18,615044206 & Rooiberg & loamy & high \\
\hline 3 & $-31,412453587$ & 18,651457876 & Quaggaskop & quartz & moderate \\
\hline 4 & $-31,346700574$ & 18,467322865 & Hoogstaan & quartz & high \\
\hline 5 & $-31,338585529$ & 18,575364926 & Ratelgat & quartz & moderate \\
\hline 6 & $-31,448367024$ & 18,566700071 & Rooiberg & quartz & high \\
\hline 7 & $-31,423773850$ & 18,640704900 & Quaggaskop & loamy & moderate \\
\hline 8 & $-31,368514979$ & 18,457467109 & Hoogstaan & loamy & high \\
\hline
\end{tabular}

Appendix 2 GPS-data of the trapping plots in chronological order. Reference system: WGS 84.

\begin{tabular}{|c|c|c|c|c|c|}
\hline Trap Plot & Latitude & Longitude & Farm & Habitat & Grazing intensity \\
\hline 1 & $-31,344442153$ & 18,602520973 & Ratelgat & loamy & medium \\
\hline 2 & $-31,339607472$ & 18,472908586 & Hoogstaan & loamy & high \\
\hline 3 & $-31,413479531$ & 18,648974150 & Quaggaskop & quartz & medium \\
\hline 4 & $-31,410715515$ & 18,591518551 & Rooiberg & quartz & high \\
\hline 5 & $-31,404828066$ & 18,636589050 & Quaggaskop & loamy & medium \\
\hline 6 & $-31,406843725$ & 18,613791615 & Rooiberg & loamy & high \\
\hline 7 & $-31,345537836$ & 18,597935736 & Ratelgat & quartz & medium \\
\hline 8 & $-31,346408213$ & 18,466046155 & Hoogstaan & quartz & high \\
\hline 9 & $-31,353461081$ & 18,566109985 & Ratelgat & loamy & medium \\
\hline 10 & $-31,356473202$ & 18,463255316 & Hoogstaan & loamy & high \\
\hline 11 & $-31,417492116$ & 18,596685827 & Rooiberg & quartz & high \\
\hline 12 & $-31,406900073$ & 18,626927733 & Rooiberg & loamy & high \\
\hline 13 & $-31,411762897$ & 18,650787324 & Quaggaskop & quartz & medium \\
\hline 14 & $-31,394545818$ & 18,652713150 & Quaggaskop & loamy & medium \\
\hline 15 & $-31,350294734$ & 18,464320153 & Hoogstaan & quartz & high \\
\hline 16 & $-39,178602055$ & 18,575264365 & Ratelgat & quartz & medium \\
\hline 17 & $-39,223985032$ & 18,553024828 & Ratelgat & loamy & medium \\
\hline 18 & $-39,309477762$ & 18,565498441 & Rooiberg & quartz & high \\
\hline 19 & $-39,300693528$ & 18,585923463 & Rooiberg & loamy & high \\
\hline 20 & $-39,277889387$ & 18,640273064 & Quaggaskop & loamy & medium \\
\hline 21 & $-39,257206873$ & 18,648830652 & Quaggaskop & quartz & medium \\
\hline 22 & $-31,369046057$ & 18,456895798 & Hoogstaan & loamy & high \\
\hline
\end{tabular}


Appendix 3 Shannon index, evenness, total number of individuals and total number of species, total and mean vegetation cover [\%] per trap plot, habitat, farm and grazing intensity. Shannon index is only defined for species richness $\leq 1$ and evenness for species richness $\leq 2$.

\begin{tabular}{|c|c|c|c|c|c|c|c|c|c|c|c|c|}
\hline $\begin{array}{l}\text { Trap } \\
\text { Plot }\end{array}$ & Habitat & Farm & $\begin{array}{l}\text { Grazing } \\
\text { intensity }\end{array}$ & Hs & $\mathbf{H}_{\max }$ & 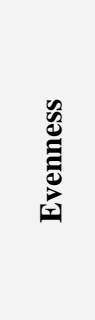 & 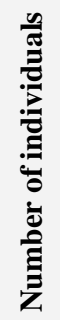 & 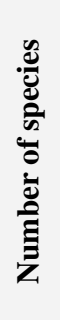 & 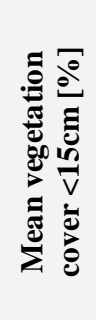 & 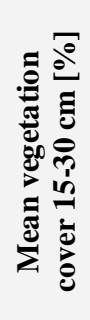 & 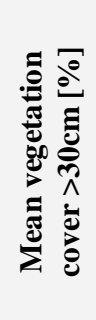 & $\begin{array}{l}\frac{5}{30} \\
\frac{1}{0} \\
\frac{0}{0} \\
\frac{\pi}{0} \\
\text { है }\end{array}$ \\
\hline 1 & loamy & Ratelgat & moderate & 1.455 & 1.609 & 0.904 & 16 & 5 & 8.92 & 8.33 & 6.16 & 23.41 \\
\hline 2 & loamy & Hoogstaan & intensive & 0.000 & 0.000 & n.a. & 2 & 1 & 8.32 & 3.78 & 1.18 & 13.28 \\
\hline 3 & quartz & Quaggaskop & moderate & n.a. & n.a. & n.a. & 0 & 0 & 11.22 & 7.97 & 3.10 & 22.28 \\
\hline 4 & quartz & Rooiberg & intensive & n.a. & n.a. & n.a. & 0 & 0 & 4.49 & 6.66 & 1.23 & 12.38 \\
\hline 5 & loamy & Quaggaskop & moderate & n.a. & n.a. & n.a. & 0 & 0 & 14.77 & 5.92 & 0.62 & 21.32 \\
\hline 6 & loamy & Rooiberg & intensive & n.a. & n.a. & n.a. & 0 & 0 & 12.64 & 5.97 & 2.08 & 20.69 \\
\hline 7 & quartz & Ratelgat & moderate & 0.000 & 0.000 & n.a. & 1 & 1 & 5.99 & 3.08 & 1.04 & 10.12 \\
\hline 8 & quartz & Hoogstaan & intensive & n.a. & n.a. & n.a. & 0 & 0 & 10.27 & 5.11 & 2.09 & 17.47 \\
\hline 9 & loamy & Ratelgat & moderate & 0.000 & 0.000 & n.a. & 1 & 1 & 7.49 & 4.91 & 1.46 & 13.85 \\
\hline 10 & loamy & Hoogstaan & intensive & 0.562 & 0.693 & 0.811 & 4 & 2 & 5.71 & 7.23 & 4.83 & 17.78 \\
\hline 11 & quartz & Rooiberg & intensive & n.a. & n.a. & n.a. & 0 & 0 & 3.72 & 1.73 & 0.22 & 5.68 \\
\hline 12 & loamy & Rooiberg & intensive & 0.000 & 0.000 & n.a. & 1 & 1 & 10.23 & 6.43 & 3.00 & 19.67 \\
\hline 13 & quartz & Quaggaskop & moderate & 0.000 & 0.000 & n.a. & 1 & 1 & 3.91 & 0.46 & 0.00 & 4.37 \\
\hline 14 & loamy & Quaggaskop & moderate & 1.330 & 1.386 & 0.959 & 6 & 4 & 10.44 & 3.91 & 1.50 & 15.86 \\
\hline 15 & quartz & Hoogstaan & intensive & 0.377 & 0.693 & 0.544 & 8 & 2 & 3.43 & 1.98 & 2.64 & 8.06 \\
\hline 16 & quartz & Ratelgat & moderate & 0.000 & 0.000 & n.a. & 2 & 1 & 3.98 & 1.53 & 0.93 & 6.44 \\
\hline 17 & loamy & Ratelgat & moderate & 0.000 & 0.000 & n.a. & 2 & 1 & 5.89 & 3.98 & 1.07 & 10.93 \\
\hline 18 & quartz & Rooiberg & intensive & 0.000 & 0.000 & n.a. & 2 & 1 & 2.93 & 1.43 & 0.58 & 4.94 \\
\hline 19 & loamy & Rooiberg & intensive & 1.073 & 1.386 & 0.774 & 41 & 4 & 4.38 & 5.17 & 6.88 & 16.42 \\
\hline 20 & loamy & Quaggaskop & moderate & 1.798 & 1.946 & 0.924 & 18 & 7 & 9.54 & 7.98 & 1.78 & 19.30 \\
\hline 21 & quartz & Quaggaskop & moderate & 0.868 & 1.099 & 0.790 & 6 & 3 & 4.00 & 2.01 & 1.58 & 7.59 \\
\hline 22 & loamy & Hoogstaan & intensive & 1.076 & 1.386 & 0.776 & 29 & 4 & 3.96 & 6.37 & 6.61 & 16.93 \\
\hline
\end{tabular}


Appendix 4 Mean weather data and moon data per trap plot.

\begin{tabular}{|c|c|c|c|c|c|c|c|}
\hline 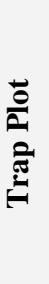 & 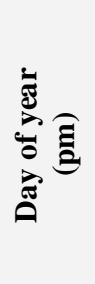 & 这 & 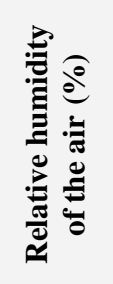 & 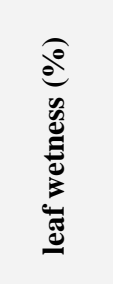 & 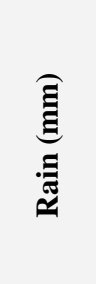 & 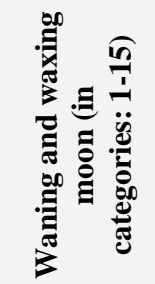 & 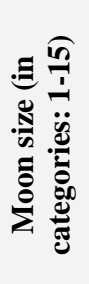 \\
\hline 1 & 222 & 10.967 & 82.800 & 24.250 & 0.003 & decreasing & 2.5 \\
\hline 2 & 226 & 11.528 & 77.867 & 30.350 & 0.033 & increasing & 3.5 \\
\hline 3 & 231 & 11.480 & 84.533 & 10.483 & 0.003 & increasing & 8.5 \\
\hline 4 & 232 & 10.805 & 84.100 & 9.567 & 0.003 & increasing & 9.5 \\
\hline 5 & 238 & 11.095 & 86.883 & 37.183 & 0.013 & increasing & 14.5 \\
\hline 6 & 238 & 11.095 & 86.883 & 37.183 & 0.013 & increasing & 14.5 \\
\hline 7 & 245 & 10.817 & 81.067 & 1.333 & 0.000 & decreasing & 8.5 \\
\hline 8 & 258 & 12.945 & 71.033 & 19.133 & 0.033 & increasing & 6.5 \\
\hline 9 & 259 & 13.895 & 70.800 & 28.683 & 0.033 & increasing & 7.5 \\
\hline 10 & 262 & 13.817 & 79.317 & 24.500 & 0.017 & increasing & 10.5 \\
\hline 11 & 274 & 13.555 & 77.433 & 57.000 & 0.043 & decreasing & 9.5 \\
\hline 12 & 275 & 12.133 & 83.300 & 36.300 & 0.043 & decreasing & 8.5 \\
\hline 13 & 278 & 10.598 & 76.850 & 18.200 & 0.057 & decreasing & 5.5 \\
\hline 14 & 281 & 14.610 & 58.450 & 23.833 & 0.000 & decreasing & 2.5 \\
\hline 15 & 282 & 15.697 & 63.650 & 48.033 & 0.000 & decreasing & 2 \\
\hline 16 & 289 & 20.433 & 47.183 & 19.583 & 0.000 & increasing & 7.5 \\
\hline 17 & 290 & 20.305 & 48.183 & 14.583 & 0.000 & increasing & 8.5 \\
\hline 18 & 293 & 15.777 & 78.200 & 29.217 & 0.007 & increasing & 11.5 \\
\hline 19 & 294 & 16.122 & 69.033 & 23.183 & 0.007 & increasing & 12.5 \\
\hline 20 & 301 & 17.392 & 75.683 & 15.000 & 0.000 & decreasing & 12.5 \\
\hline 21 & 301 & 17.392 & 75.683 & 15.000 & 0.000 & decreasing & 12.5 \\
\hline 22 & 305 & 15.468 & 76.850 & 14.017 & 0.020 & decreasing & 8.5 \\
\hline
\end{tabular}


Appendix 5 Caught and measured Individuals of the striped mouse Rhabdomys pumilio.

\begin{tabular}{|c|c|c|c|c|c|c|c|c|c|c|c|c|c|c|}
\hline $\begin{array}{l}\text { Trap } \\
\text { Plot }\end{array}$ & $\begin{array}{c}\text { Capture } \\
\text { day }\end{array}$ & Date & $\begin{array}{c}\text { Day } \\
\text { of } \\
\text { year }\end{array}$ & Farm & $\begin{array}{l}\text { Grazing } \\
\text { intensity }\end{array}$ & Habitat & Sex & $\begin{array}{c}\text { Weight } \\
\text { [g] }\end{array}$ & $\begin{array}{c}\text { Tarsus } \\
\text { length } \\
{[\mathrm{mm}]}\end{array}$ & BMI & 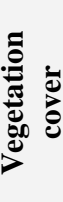 & 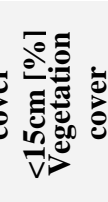 & & 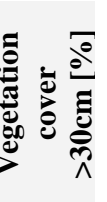 \\
\hline 1 & 2 & 11.08.2007 & 224 & Ratelgat & moderate & loamy & male & 48 & 25.20 & 1.90 & 5 & 30 & 0 & 40 \\
\hline 1 & 3 & 12.08 .2007 & 225 & Ratelgat & moderate & loamy & male & 51 & 23.10 & 2.21 & 5 & 2 & 2 & 30 \\
\hline 1 & 4 & 13.08.2007 & 226 & Ratelgat & moderate & loamy & - & - & - & - & 5 & 30 & 0 & 0 \\
\hline 10 & 1 & 19.09.2007 & 263 & Hoogstaan & intensive & loamy & male & 55 & 22.70 & 2.42 & 0 & 0 & O & 15 \\
\hline 13 & 2 & 06.10 .2007 & 280 & Quaggaskop & moderate & quartz & male & 20 & 21.40 & 0.93 & 2 & 0 & 0 & 0 \\
\hline 19 & 1 & 21.10 .2007 & 295 & Rooiberg & intensive & loamy & male & 18 & 21.40 & 0.84 & 30 & 5 & 5 & 10 \\
\hline 19 & 1 & 21.10 .2007 & 295 & Rooiberg & intensive & loamy & male & 37 & 25.20 & 1.47 & 9 & 0 & 0 & 0 \\
\hline 19 & 1 & 21.10 .2007 & 295 & Rooiberg & intensive & loamy & male & 19 & 34.10 & 0.56 & 6 & 0 & 0 & 0 \\
\hline 19 & 2 & 22.10 .2007 & 296 & Rooiberg & intensive & loamy & male & 52 & 25.20 & 2.06 & 5 & 2 & 2 & 0 \\
\hline 19 & 2 & 22.10 .2007 & 296 & Rooiberg & intensive & loamy & male & 21 & 23.00 & 0.91 & 3 & 0 & 0 & 40 \\
\hline 19 & 2 & 22.10 .2007 & 296 & Rooiberg & intensive & loamy & male & 23 & 24.00 & 0.96 & 5 & 20 & 0 & 40 \\
\hline 19 & 2 & 22.10 .2007 & 296 & Rooiberg & intensive & loamy & male & 18 & 22.00 & 0.82 & 5 & 20 & 0 & 40 \\
\hline 19 & 2 & 22.10 .2007 & 296 & Rooiberg & intensive & loamy & male & 19 & 33.40 & 0.57 & 30 & 5 & 5 & 10 \\
\hline 19 & 2 & 22.10 .2007 & 296 & Rooiberg & intensive & loamy & male & 41 & 25.70 & 1.60 & 9 & 0 & 0 & 0 \\
\hline 19 & 2 & 22.10 .2007 & 296 & Rooiberg & intensive & loamy & male & 52 & 21.60 & 2.41 & 20 & 7 & 7 & 7 \\
\hline 19 & 3 & 23.10 .2007 & 297 & Rooiberg & intensive & loamy & male & 40 & 24.60 & 1.63 & 1 & 4 & 4 & 0 \\
\hline 19 & 3 & 23.10 .2007 & 297 & Rooiberg & intensive & loamy & male & 69 & 25.50 & 2.71 & 3 & 2 & 2 & 0 \\
\hline 19 & 3 & 23.10 .2007 & 297 & Rooiberg & intensive & loamy & male & 17 & 20.20 & 0.84 & 4 & 2 & 2 & 4 \\
\hline 19 & 3 & 23.10 .2007 & 297 & Rooiberg & intensive & loamy & male & 24 & 24.00 & 1.00 & 20 & 0 & 0 & 1 \\
\hline 19 & 3 & 23.10 .2007 & 297 & Rooiberg & intensive & loamy & male & 20 & 23.40 & 0.85 & 5 & 10 & 0 & 0 \\
\hline 19 & 3 & 23.10 .2007 & 297 & Rooiberg & intensive & loamy & male & 22 & 23.30 & 0.94 & 5 & 5 & 5 & 5 \\
\hline 19 & 3 & 23.10 .2007 & 297 & Rooiberg & intensive & loamy & male & 23 & 24.20 & 0.95 & 30 & 5 & 5 & 10 \\
\hline 19 & 4 & 24.10 .2007 & 298 & Rooiberg & intensive & loamy & male & 29 & 29.60 & 0.98 & 0 & 5 & 5 & 0 \\
\hline 19 & 4 & 24.10 .2007 & 298 & Rooiberg & intensive & loamy & male & 20 & 22.00 & 0.91 & 1 & 0 & 0 & 0 \\
\hline 19 & 4 & 24.10 .2007 & 298 & Rooiberg & intensive & loamy & male & - & - & - & 30 & 5 & 5 & 10 \\
\hline 19 & 4 & 24.10 .2007 & 298 & Rooiberg & intensive & loamy & male & 22 & 24.00 & 0.92 & 0 & 0 & 0 & 70 \\
\hline 19 & 4 & 24.10 .2007 & 298 & Rooiberg & intensive & loamy & female & 44 & 23.50 & 1.87 & 0 & 25 & 5 & 35 \\
\hline 20 & 1 & 28.10 .2007 & 302 & Quaggaskop & moderate & loamy & male & 48 & 26.00 & 1.85 & 40 & 15 & 5 & 10 \\
\hline 20 & 2 & 29.10 .2007 & 303 & Quaggaskop & moderate & loamy & female & 46 & 24.20 & 1.90 & 5 & 4 & 4 & 0 \\
\hline 21 & 2 & 29.10 .2007 & 303 & Quaggaskop & moderate & quartz & female & 47 & 26.20 & 1.79 & 3 & 5 & 5 & 20 \\
\hline 20 & 3 & 30.10 .2007 & 304 & Quaggaskop & moderate & loamy & male & 34 & 25.00 & 1.36 & 0 & 0 & 0 & 0 \\
\hline 22 & 1 & 01.11 .2007 & 306 & Hoogstaan & intensive & loamy & male & 27 & 24.50 & 1.10 & 5 & 20 & 0 & 0 \\
\hline 22 & 2 & 02.11 .2007 & 307 & Hoogstaan & intensive & loamy & female & 53 & 27.40 & 1.93 & 5 & 20 & 0 & 0 \\
\hline 22 & 2 & 02.11 .2007 & 307 & Hoogstaan & intensive & loamy & male & 52 & 25.30 & 2.06 & 1 & 5 & 5 & 0 \\
\hline 22 & 2 & 02.11 .2007 & 307 & Hoogstaan & intensive & loamy & male & 30 & 25.60 & 1.17 & 0 & 10 & 0 & 0 \\
\hline 22 & 3 & 03.11 .2007 & 308 & Hoogstaan & intensive & loamy & male & 57 & 25.00 & 2.28 & 15 & 20 & 0 & 15 \\
\hline 22 & 3 & 03.11 .2007 & 308 & Hoogstaan & intensive & loamy & female & 56 & 25.50 & 2.20 & 1 & 5 & 5 & 0 \\
\hline 22 & 3 & 03.11 .2007 & 308 & Hoogstaan & intensive & loamy & female & 39 & 29.70 & 1.31 & 5 & 10 & 0 & 10 \\
\hline 22 & 3 & 03.11 .2007 & 308 & Hoogstaan & intensive & loamy & male & 8 & 19.00 & 0.42 & 0 & 10 & 0 & 3 \\
\hline 22 & 3 & 03.11 .2007 & 308 & Hoogstaan & intensive & loamy & male & 33 & 23.70 & 1.39 & 4 & 0 & 0 & 30 \\
\hline 22 & 3 & 03.11 .2007 & 308 & Hoogstaan & intensive & loamy & male & 39 & 24.50 & 1.59 & 0 & 0 & 0 & 60 \\
\hline 22 & 4 & 04.11 .2007 & 309 & Hoogstaan & intensive & loamy & male & 43 & 22.50 & 1.91 & 0 & 0 & 0 & 30 \\
\hline 22 & 4 & 04.11 .2007 & 309 & Hoogstaan & intensive & loamy & male & 65 & 24.70 & 2.63 & 0 & 25 & 5 & 0 \\
\hline
\end{tabular}


Appendix 6 Caught and measured Individuals of the elephant shrew Macroscelides proboscideus.

\begin{tabular}{|c|c|c|c|c|c|c|c|c|c|c|c|c|c|}
\hline $\begin{array}{l}\text { Trap } \\
\text { Plot }\end{array}$ & $\begin{array}{c}\text { Capture } \\
\text { day }\end{array}$ & Date & $\begin{array}{c}\text { Day } \\
\text { of } \\
\text { year }\end{array}$ & Farm & $\begin{array}{l}\text { Grazing } \\
\text { intensity }\end{array}$ & Habitat & Sex & $\begin{array}{c}\text { Weight } \\
\text { [g] }\end{array}$ & $\begin{array}{c}\text { Tarsus } \\
\text { length } \\
{[\mathrm{mm}]}\end{array}$ & BMI & 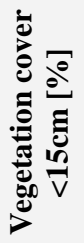 & 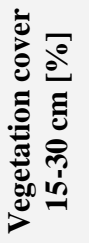 & 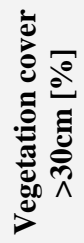 \\
\hline 1 & 1 & 10.08 .2007 & 223 & Ratelgat & moderate & loamy & male & 57 & 22.30 & 2.56 & 1 & 9 & 15 \\
\hline 1 & 1 & 10.08 .2007 & 223 & Ratelgat & moderate & loamy & male & 42 & 32.00 & 1.31 & 5 & 30 & 0 \\
\hline 1 & 2 & 11.08 .2007 & 224 & Ratelgat & moderate & loamy & female & 57 & 33.40 & 1.71 & 1 & 4 & 0 \\
\hline 1 & 2 & 11.08.2007 & 224 & Ratelgat & moderate & loamy & female & 43 & 30.40 & 1.41 & 7 & 0 & 0 \\
\hline 1 & 3 & 12.08 .2007 & 225 & Ratelgat & moderate & loamy & female & 52 & 39.00 & 1.33 & 3 & 15 & 70 \\
\hline 1 & 3 & 12.08 .2007 & 225 & Ratelgat & moderate & loamy & female & 41 & 37.30 & 1.10 & 2 & 30 & 0 \\
\hline 1 & 4 & 13.08 .2007 & 226 & Ratelgat & moderate & loamy & male & 42 & 35.00 & 1.20 & 25 & 15 & 0 \\
\hline 7 & 4 & 05.09.2007 & 249 & Ratelgat & moderate & quartz & female & 49 & 33.90 & 1.45 & 10 & 0 & 0 \\
\hline 10 & 1 & 19.09.2007 & 263 & Hoogstaan & intensive & loamy & male & 44 & 36.00 & 1.22 & 10 & 0 & 0 \\
\hline 10 & 3 & 21.09.2007 & 265 & Hoogstaan & intensive & loamy & male & 48 & 35.00 & 1.37 & 0 & 10 & 5 \\
\hline 10 & 4 & 22.09 .2007 & 266 & Hoogstaan & intensive & loamy & male & 46 & 34.90 & 1.32 & 15 & 1 & 0 \\
\hline 15 & 1 & 09.10 .2007 & 283 & Hoogstaan & intensive & quartz & female & 57 & 35.50 & 1.61 & 5 & 4 & 0 \\
\hline 15 & 1 & 09.10 .2007 & 283 & Hoogstaan & intensive & quartz & female & 31 & 32.50 & 0.95 & 4 & 0 & 0 \\
\hline 15 & 1 & 09.10 .2007 & 283 & Hoogstaan & intensive & quartz & female & 32 & 33.20 & 0.96 & 0 & 7 & 3 \\
\hline 15 & 1 & 09.10 .2007 & 283 & Hoogstaan & intensive & quartz & male & 33 & 33.60 & 0.98 & 0 & 0 & 0 \\
\hline 15 & 3 & 11.10 .2007 & 285 & Hoogstaan & intensive & quartz & male & 35 & 34.30 & 1.02 & 5 & 25 & 0 \\
\hline 15 & 4 & 12.10 .2007 & 286 & Hoogstaan & intensive & quartz & male & 33 & 32.90 & 1.00 & 0 & 1 & 0 \\
\hline 15 & 4 & 12.10 .2007 & 286 & Hoogstaan & intensive & quartz & male & 37 & 35.20 & 1.05 & 3 & 5 & 0 \\
\hline 18 & 1 & 20.10 .2007 & 294 & Rooiberg & intensive & quartz & female & 30 & 33.40 & 0.90 & 1 & 0 & 0 \\
\hline 18 & 2 & 21.10 .2007 & 295 & Rooiberg & intensive & quartz & male & 42 & 34.00 & 1.24 & 4 & 0 & 0 \\
\hline 19 & 3 & 23.10 .2007 & 297 & Rooiberg & intensive & loamy & male & 39 & 36.30 & 1.07 & 2 & 0 & 0 \\
\hline 19 & 3 & 23.10 .2007 & 297 & Rooiberg & intensive & loamy & female & 42 & 36.00 & 1.17 & 4 & 0 & 0 \\
\hline 19 & 3 & 23.10 .2007 & 297 & Rooiberg & intensive & loamy & female & 44 & 34.80 & 1.26 & 1 & 0 & 0 \\
\hline 19 & 4 & 24.10 .2007 & 298 & Rooiberg & intensive & loamy & male & 38 & 34.60 & 1.10 & 4 & 0 & 0 \\
\hline 20 & 1 & 28.10 .2007 & 302 & Quaggaskop & moderate & loamy & male & 37 & 35.50 & 1.04 & 20 & 0 & 0 \\
\hline 20 & 2 & 29.10 .2007 & 303 & Quaggaskop & moderate & loamy & male & 35 & 34.60 & 1.01 & 4 & 10 & 0 \\
\hline 21 & 4 & 31.10 .2007 & 305 & Quaggaskop & moderate & quartz & male & 42 & 34.30 & 1.22 & 15 & 10 & 5 \\
\hline 22 & 1 & 01.11 .2007 & 306 & Hoogstaan & intensive & loamy & female & 49 & 34.40 & 1.42 & 0 & 0 & 0 \\
\hline 22 & 1 & 01.11 .2007 & 306 & Hoogstaan & intensive & loamy & male & 43 & 36.90 & 1.17 & 2 & 4 & 0 \\
\hline 22 & 1 & 01.11 .2007 & 306 & Hoogstaan & intensive & loamy & female & 40 & 37.40 & 1.07 & 0 & 20 & 4 \\
\hline 22 & 2 & 02.11 .2007 & 307 & Hoogstaan & intensive & loamy & male & 41 & 36.50 & 1.12 & 5 & 5 & 0 \\
\hline 22 & 2 & 02.11 .2007 & 307 & Hoogstaan & intensive & loamy & male & 40 & 35.20 & 1.14 & 1 & 25 & 0 \\
\hline 22 & 3 & 03.11 .2007 & 308 & Hoogstaan & intensive & loamy & female & 33 & 36.40 & 0.91 & 5 & 20 & 0 \\
\hline 22 & 3 & 03.11 .2007 & 308 & Hoogstaan & intensive & loamy & female & 40 & 36.20 & 1.10 & 5 & 5 & 0 \\
\hline 22 & 3 & 03.11 .2007 & 308 & Hoogstaan & intensive & loamy & female & 58 & 35.90 & 1.62 & 0 & 10 & 0 \\
\hline 22 & 3 & 03.11 .2007 & 308 & Hoogstaan & intensive & loamy & female & 41 & 34.40 & 1.19 & 4 & 10 & 18 \\
\hline 22 & 3 & 03.11 .2007 & 308 & Hoogstaan & intensive & loamy & female & 34 & 36.70 & 0.93 & 10 & 0 & 0 \\
\hline 22 & 3 & 03.11 .2007 & 308 & Hoogstaan & intensive & loamy & female & 44 & 36.00 & 1.22 & 0 & 0 & 8 \\
\hline 22 & 4 & 04.11 .2007 & 309 & Hoogstaan & intensive & loamy & male & 47 & 37.00 & 1.27 & 0 & 0 & 38 \\
\hline 22 & 4 & 04.11 .2007 & 309 & Hoogstaan & intensive & loamy & male & 43 & 35.20 & 1.22 & 0 & 0 & 0 \\
\hline
\end{tabular}


Appendix 7 Overview of Spearman rank correlation results of weather data and day of year for the analyses of trapped small mammals.

\begin{tabular}{|c|c|c|c|c|c|c|c|}
\hline & $\begin{array}{c}\text { Day } \\
\text { of } \\
\text { year } \\
(\mathbf{p m})\end{array}$ & $\begin{array}{c}\text { Air } \\
\text { temperature } \\
\left({ }^{\circ} \mathrm{C}\right)\end{array}$ & $\begin{array}{c}\text { Relative } \\
\text { humidity } \\
\text { of the air } \\
(\%)\end{array}$ & $\begin{array}{c}\text { Leaf } \\
\text { wetness } \\
(\%)\end{array}$ & $\begin{array}{l}\text { Rain } \\
(\mathbf{m m})\end{array}$ & $\begin{array}{c}\text { Waning } \\
\text { and waxing } \\
\text { moon (in } \\
\text { categories: } \\
1-15)\end{array}$ & $\begin{array}{c}\text { Moon } \\
\text { size (in } \\
\text { categorie } \\
\text { s: } 1 \text {-15) }\end{array}$ \\
\hline Day of year (pm) & 1.00 & 0.79 & -0.63 & -0.15 & -0.26 & -0.30 & 0.21 \\
\hline Air temperature $\left({ }^{\circ} \mathrm{C}\right)$ & 0.79 & 1.00 & -0.74 & 0.00 & -0.43 & 0.04 & 0.12 \\
\hline $\begin{array}{l}\text { Relative humidity of the air } \\
(\%)\end{array}$ & -0.63 & -0.74 & 1.00 & 0.10 & 0.31 & 0.10 & 0.39 \\
\hline Leaf wetness $(\%)$ & -0.15 & 0.00 & 0.10 & 1.00 & 0.40 & 0.04 & 0.00 \\
\hline Rain $(\mathbf{m m})$ & -0.26 & -0.43 & 0.31 & 0.40 & 1.00 & 0.10 & -0.02 \\
\hline $\begin{array}{l}\text { Waning and waxing moon (in } \\
\text { categories: } 1-15 \text { ) }\end{array}$ & -0.30 & 0.04 & 0.10 & 0.04 & 0.10 & 1.00 & 0.27 \\
\hline Moon size (in categories: $1-15$ ) & 0.21 & 0.12 & 0.39 & 0.00 & -0.02 & 0.27 & 1.00 \\
\hline
\end{tabular}

Appendix 8 Overview of Spearman rank correlation results of weather data and day of year for the analyses of the missing seeds.

\begin{tabular}{|c|c|c|c|c|c|c|c|}
\hline & $\begin{array}{c}\text { Day } \\
\text { of } \\
\text { year } \\
(\mathrm{pm})\end{array}$ & $\begin{array}{c}\text { Air } \\
\text { temperature } \\
\left({ }^{\circ} \mathrm{C}\right)\end{array}$ & $\begin{array}{c}\text { Relative } \\
\text { humidity } \\
\text { of the air } \\
(\%)\end{array}$ & $\begin{array}{c}\text { Leaf } \\
\text { wetness } \\
(\%)\end{array}$ & $\begin{array}{l}\text { Rain } \\
(\mathbf{m m})\end{array}$ & $\begin{array}{c}\text { Waning } \\
\text { and waxing } \\
\text { moon (in } \\
\text { categories: } \\
1-15)\end{array}$ & $\begin{array}{l}\text { Moon size } \\
\text { (in } \\
\text { categories: } \\
1-15 \text { ) }\end{array}$ \\
\hline Day of year (pm) & 1.00 & 0.13 & 0.24 & -0.14 & -0.08 & 0.19 & 0.24 \\
\hline Air temperature $\left({ }^{\circ} \mathrm{C}\right)$ & 0.13 & 1.00 & -0.64 & -0.10 & -0.25 & -0.47 & 0.35 \\
\hline $\begin{array}{l}\text { Relative humidity of the air } \\
(\%)\end{array}$ & 0.24 & -0.64 & 1.00 & 0.42 & 0.49 & 0.40 & 0.07 \\
\hline Leaf wetness (\%) & -0.14 & -0.10 & 0.42 & 1.00 & 0.40 & -0.016 & -0.07 \\
\hline Rain (mm) & -0.08 & -0.25 & 0.49 & 0.40 & 1.00 & 0.19 & -0.03 \\
\hline $\begin{array}{l}\text { Waning and waxing moon (in } \\
\text { categories: } 1-15 \text { ) }\end{array}$ & 0.19 & -0.47 & 0.40 & -0.01 & 0.19 & 1.00 & -0.17 \\
\hline Moon size (in categories: $1-15$ ) & 0.24 & 0.35 & 0.07 & -0.07 & -0.03 & -0.17 & 1.00 \\
\hline
\end{tabular}

Appendix 9 Number of seedlings per family, taxa and grazing intensity. Points indicate no seedlings.

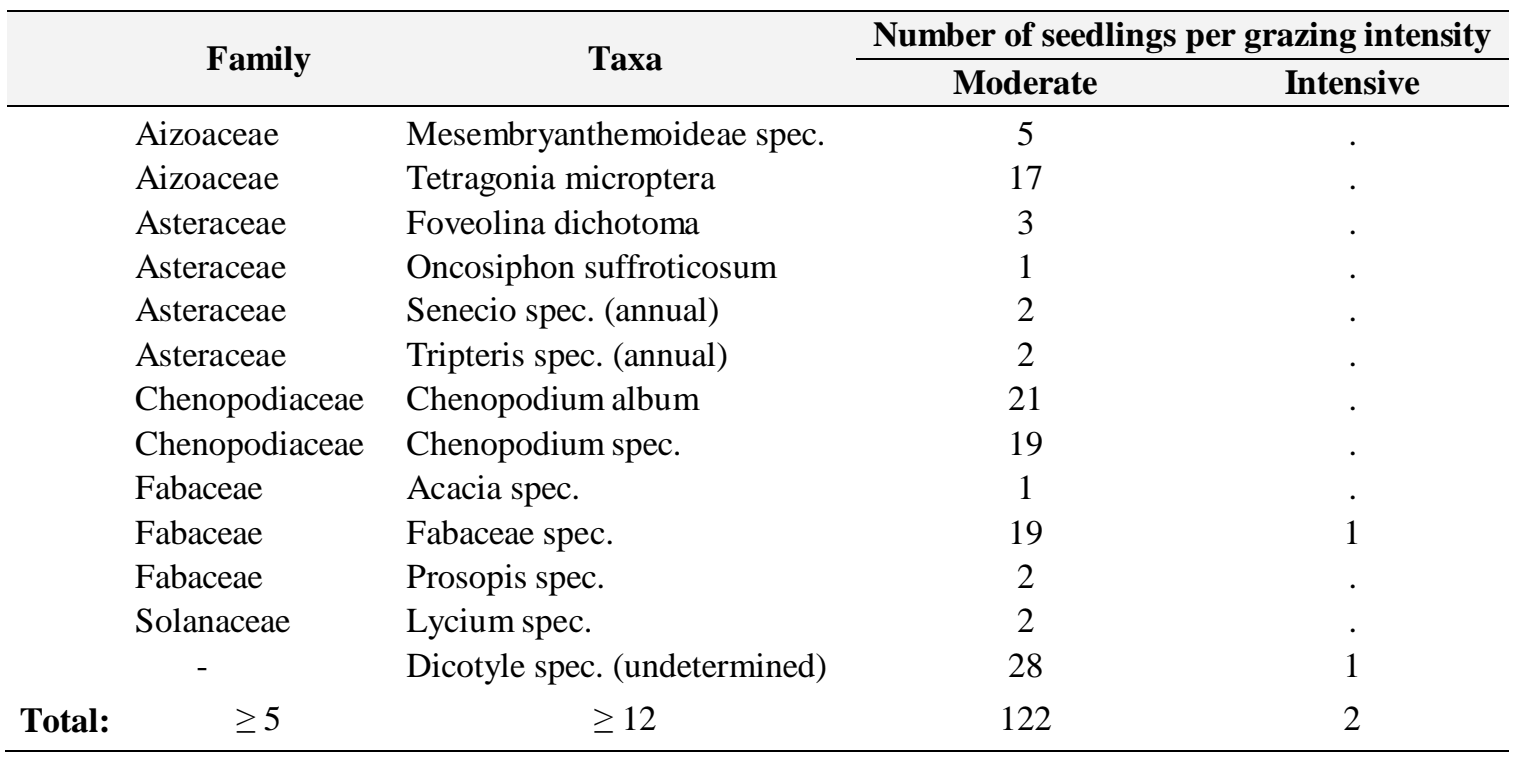


Appendix 10 Reddish-grey musk shrew

Crocidura cyanea.

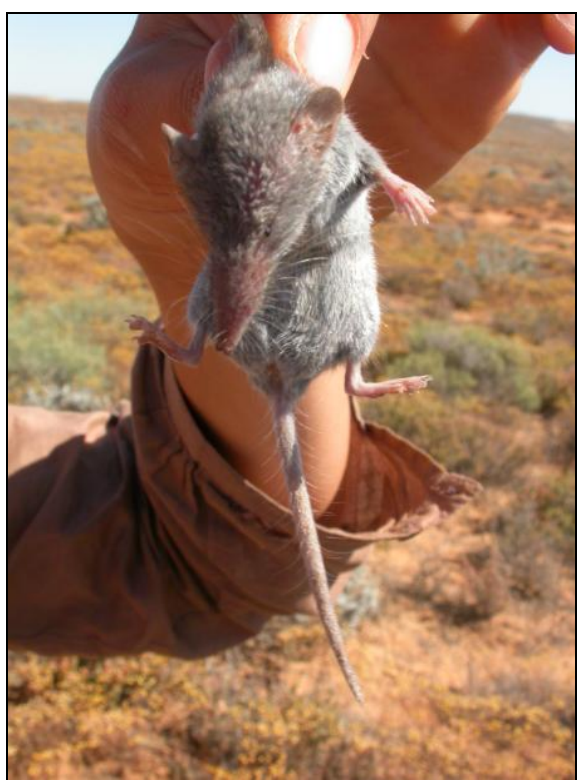

Appendix 12 Hairy-footed Gerbil Gerbillurus paeba.

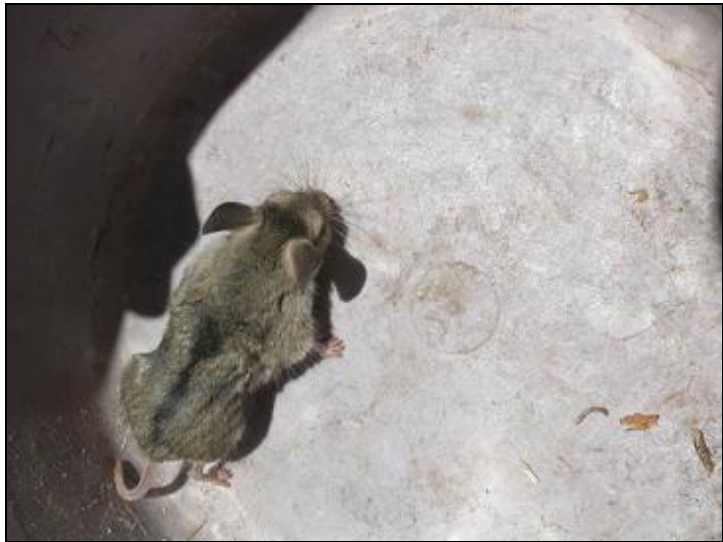

Appendix 14 Pygmy Mouse Mus minutoides.

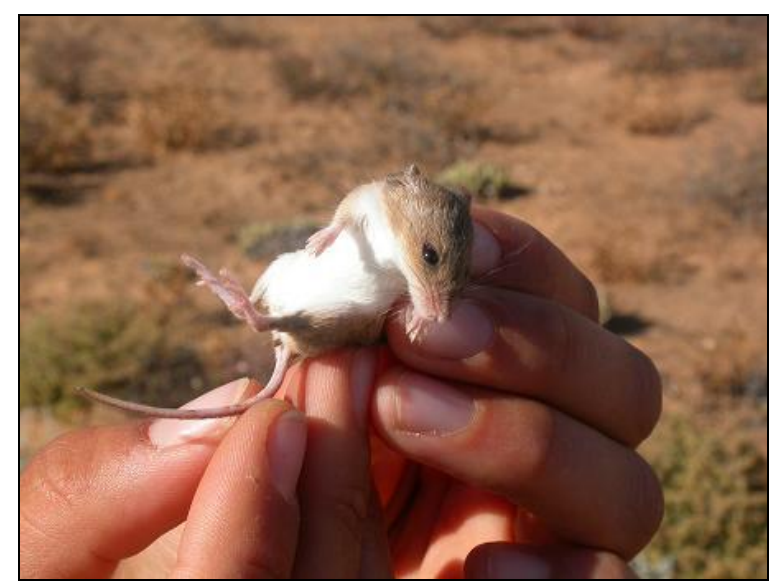

Appendix 11 Bush Karoo Rat Otomys unisulcatus.

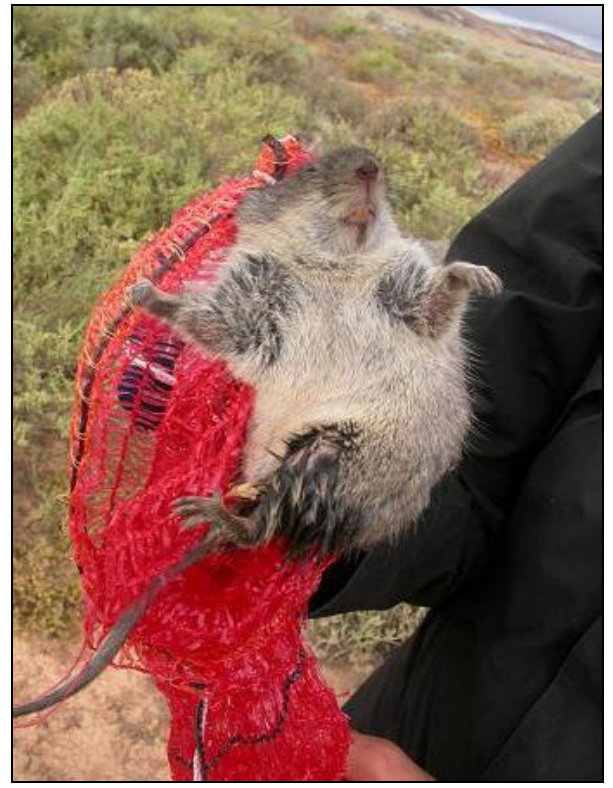

Appendix 13 Gerbil mouse Malacothrix typica.

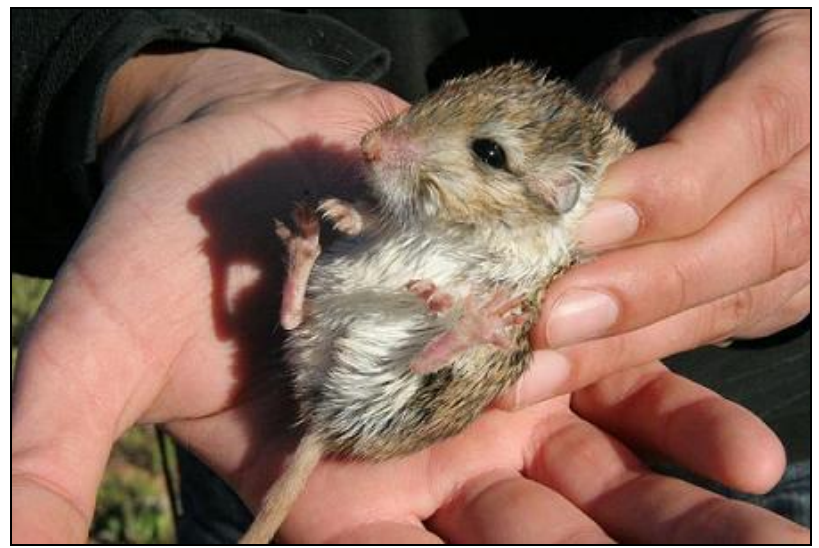

Appendix 15 Short-tailed Gerbil Desmodillus auricularis.

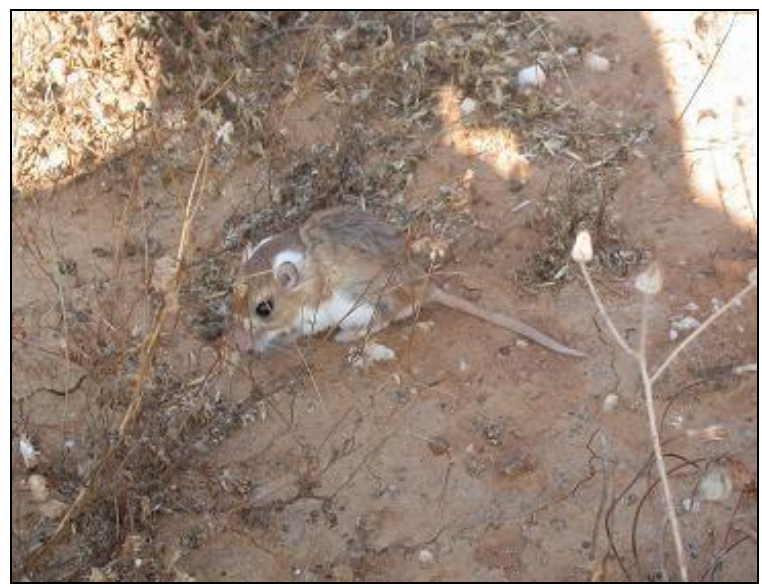


Appendix 16 Contents of electronic appendices.

Appendix

Electronic Appendix 1

Electronic Appendix 2

Electronic Appendix 3

Electronic Appendix 4

\section{Content}

Access-Database with all raw data abbreviations of electronic appendices pictures of trap plots and exclosure plots electronic version of diploma thesis 


\section{Acknowledgements}

Am meisten danke ich Ute Schmiedel für ihre geduldige fachliche Unterstützung während der Feldphase und der Zeit des Auswertens und Schreibens, als auch für die vielen Korrekturen, Hinweise, Anmerkungen und Hilfestellungen. Auch durch ihre Menschlichkeit, immerwährende Herzlichkeit und Wärme hat sie mir viel Halt und Mut zum weiter machen gegeben......DANKE! Bei Ute habe ich sehr viel für mein weiteres Leben gelernt, z.B. wie eine stets positive Einstellung zur Arbeit, das Faszination ansteckend sein kann, aber auch viel über den Umgang mit anderen Menschen.

Meinem Erstgutachter Jörg Ganzhorn möchte dafür danken, dass er mir bei allen fachlichen Fragen meinerseits immer das Gefühl gegeben hat willkommen zu sein.

Meinem Zweitgutachter Norbert Jürgens danke ich dafür, dass ich meine Diplomarbeit innerhalb des BIOTA-Projektes schreiben durfte und ich durch die Feldarbeit die Möglichkeit hatte einen Teil Südafrikas kennen zu lernen.

Jürgen Dengler danke ich für die ausdauernde Unterstützung bei den statistischen Auswertungen und während des Schreibens. Ich habe bei ihm persönlich, als auch bei ihm im Paperseminar viel über das Verfassen eines wissenschaftlichen Textes gelernt.

Danielea Haarmeyer ist mir in der Zeit meiner Diplomarbeit eine Freundin geworden! Während der gemeinsamen Feldphase und in der Zeit des Schreibens sind wir gemeinsam durch viele Höhen und Tiefen gegangen. Wir hatten meist viel Spaß bei der Arbeit und vor allem beim Erholen von der Arbeit:- Ich danke Dir für die schöne Zeit!

Ich danke ganz herzlich der ganzen Arbeitsgruppe der Systematik für ihre stete Hilfsbereitschaft, Freundlichkeit und warme Aufnahme in ihren Kreis.

Für die Nutzung des Gewächshauses danke ich der ganzen Arbeitsgruppe der Angewandten Pflanzenökologie. Bei Marion Klötzl bedanke ich mich für die Anleitungen und die Hilfe im Gewächshaus.

Many thanks to Elbié Cloete for our accommodation, his support and organisation during our fieldwork and. Thanks to CapeNature for the Permit to collect flora and fauna specimens for scientific research

Die Lebendfallen und das nötige Feldequipment für die Kleinsäuger wurden mir von Connie Krug, University of Cape Town, South Africa zur Verfügung gestellt. Ihr danke ich für die Hilfe bei der Identifizierung der Kleinsäuger und für die Unterstützung bei der Literatursuche. 
Very special thanks to Henry Combring for his suggestions and the support of our work, showing us the beautiful landscape. In addition, thanks for the good wine and the funny evenings in the farm.

I am grateful to Wynand Pieters for his great help during the fieldwork and his friendship, for our long talks and that he taught me a lot about South Africa.

I would like to thank Henry (Nici) Cloete for his support throughout the fieldwork and his lekker Boikikos.

I would also like to thank Gerda Kriel und Marianna Beukes-Joseph for their support during the fieldwork and the funny lunch breaks.

I would like to thank Sessil and the Griequa community for their interviews and that we had the possibility to make our investigations on their farm Ratelgat. I would like to thank Boys Wiese, the owner of Quaggaskop, who allowed us to make our investigations on his farm. Furthermore, I would like to thank Marietjie Fandermerwe, the owner of Hoogstaan, who allowed us to make our investigations on his farm.

Thanks a lot to the herders on Rooiberg for their interviews and that they were always friendly to us and careful with our trap plots and exclosure plots.

Ingo Homburg danke ich für die Unterstützung bei allen organisatorischen Fragen.

I would like to thank Tessa Olivier for her warm welcome in South Africa and her nice location plans.

Ich danke dem BIOTA-Projekt, der Deutschen Kakteen Gesellschaft (e.V.) und dem Deutschen Akademischen Austauschdienst (DAAD) für die finanzielle Unterstützung.

Imke Fähnders danke ich für die vielen Korrekturen und die geduldige und schnelle Hilfe bei der Übersetzung.

Ich danke dem Amt für Gesundheit und Verbraucherschutz für die Genehmigung zur Einfuhr von Kotproben zu wissenschaftlichen Zwecken.

Den Teilnehmern des Paper-Writing-Seminar (Jürgen, Ute, Manfred, Niels, Dirk, Jens, Wiebke, Jona, Inga, Anna, Magda, Oliver) danke ich für ihre konstruktive Kritik, ihre vielen Anmerkungen und auch Anregungen.

Wiebke Hanke danke ich besonders für ihren Zuspruch, ihre konstruktive Kritik, ihre Herzlichkeit und für all die schönen Pausen! Danke auch für die Hilfe im Feld. Niels Dreber danke ich für die fachliche und persönliche Unterstützung, für all die schönen Kaffeepausen, 
all die Korrekturen, für all den Zuspruch und die Ermutigungen. Dirk Wesuls sei mein herzlicher Dank ausgesprochen für seinen persönlichen Zuspruch, seine Aufmunterungen und seine Korrekturen. Jens Oldeland danke ich dafür, dass er mir bei allen Computer- und Statistikfragen immer bereitwillig weiter geholfen hat und sich stets viel Zeit für mich genommen hat. Danke dass ich bei euch vieren immer willkommen war und ihr mich immer wieder aufgemuntert habt, ich mir bei euch eine Mütze voll Ablenkung holen konnte und immer jemand Zeit für mich hatte. Ich werde euch alle sehr vermissen!

Witja Pitz danke ich für die Unterstützung während der ersten Zeit im Feld und für seine konstruktiven Ideen und sein Einbringen in die logistischen Herausforderungen die das Zusammenleben und die Arbeiten im Feld mit sich brachten.

Jona Luther-Mosebach und Matthias Hoffmeister danke ich für die geduldige Hilfe bei der Erstellung der Exclosures, als auch bei der Planung des Samenprädationsexperiments, sowie die lustigen Aufmunterungen durch ihre Reiseberichte.

Thiko Jensen danke ich für den Zuspruch und die Ermutigungen in all den anfänglichen Stunden voller Zweifel.

Ich danke Anna Wegmann und Michael Zschoche, dafür, dass sie mich so kurzfristige auf ihrem Sofa aufgenommen haben und für die vielen schönen Teestunden. Meinen Freundinnen Anna, Christina, Hanna, Simone und Katrin danke ich für die abwechslungsreichen Mädelsabende! Auch Brigitte danke ich für ihr stets offenes Ohr und ihren Zuspruch. Meinen Mitbewohnern Jan und Madleen danke ich für die schöne Zeit und die aufbauenden Worte in der WG.

Veronika Specker danke ich für den immer währenden Zuspruch.

Vielen Dank an meinen Bruder Sven Bösing, der mir immer zugesprochen hat, mich unterstützt hat und immer Anteilnahme an meinen Problemen und Sorgen zeigte.

Zum Schluss danke ich ganz besonders meinen Eltern Uwe und Hilde Bösing für ihre geduldige Unterstützung während meines ganzen Studiums. Sie haben mir stets Rückhalt gegeben und mir Mut und Selbstvertrauen vermittelt. 


\section{Erklärung}

Ich versichere, die vorliegende Arbeit selbständig verfasst und mich keiner anderen als der angegebenen Quellen und Hilfsmittel bedient zu haben. Mit einer Veröffentlichung dieser Arbeit bin ich einverstanden.

Unterschrift

Datum. 